\title{
Investigating changes in productivity of an old growth Juniperus stand: A physiological and isotopic approach
}

\author{
Scott E. Spal
}

West Virginia University

Follow this and additional works at: https://researchrepository.wvu.edu/etd

\section{Recommended Citation}

Spal, Scott E., "Investigating changes in productivity of an old growth Juniperus stand: A physiological and isotopic approach" (2012). Graduate Theses, Dissertations, and Problem Reports. 3523.

https://researchrepository.wvu.edu/etd/3523

This Thesis is protected by copyright and/or related rights. It has been brought to you by the The Research Repository @ WVU with permission from the rights-holder(s). You are free to use this Thesis in any way that is permitted by the copyright and related rights legislation that applies to your use. For other uses you must obtain permission from the rights-holder(s) directly, unless additional rights are indicated by a Creative Commons license in the record and/ or on the work itself. This Thesis has been accepted for inclusion in WVU Graduate Theses, Dissertations, and Problem Reports collection by an authorized administrator of The Research Repository @ WVU. For more information, please contact researchrepository@mail.wvu.edu. 
Investigating changes in productivity of an old growth Juniperus stand: A physiological and isotopic approach

\author{
by \\ Scott E. Spal \\ Thesis submitted to the Eberly College of liberal Arts and Sciences \\ at West Virginia University \\ in partial fulfillment of the requirements \\ for the degree of \\ Master of Science \\ in \\ Biology \\ Approved by \\ Richard B. Thomas, Ph.D., Committee Chairperson \\ William T. Peterjohn, Ph.D. \\ Amy E. Hessl, Ph.D.
}

Biology

Morgantown, West Virginia

2012

Keywords: Juniperus virginiana, photosynthesis, hydraulic conductance, stable isotopes, dendrochronology 


\section{Abstract \\ Investigating changes in productivity of an old growth Juniperus stand: \\ A physiological and isotopic approach \\ by Scott E. Spal}

Forest ecosystems play a central role in the global carbon cycle and are a major part of the terrestrial carbon sink. For more accurate predictions of terrestrial $\mathrm{C}$ sequestration models require a mechanistic understanding of how carbon cycling in trees and forests responds to atmospheric $\mathrm{CO}_{2}$, temperature, and precipitation. With this comes a need for a greater understanding of the physiological mechanisms involved with changes in forest productivity as trees and forests age. This research used an old growth stand of Juniperus virginiana (Eastern red cedar) in the Central Appalachian Mountains of West Virginia to examine how carbon assimilation changes over time. This study had two components; the first examined of how tree age affects the physiological ecology of Juniperus virginiana in their native habitat; the second used the stable $\mathrm{C}$ isotopes in the annual growth rings to determine whether we could detect how climatic and environmental factors affected $\mathrm{C}$ assimilation and growth over the last century. The first component of this study provided little evidence that age strongly affects leaf photosynthesis or hydraulic conductivity. Current environmental conditions are far more indicative of physiological functioning than tree age. However, it may be that agerelated changes in the physiology of J. virginiana occur earlier than the youngest ages of trees in this stand. The second component of this study found weak links between climate and tree productivity. Interestingly, a strong link between $\mathrm{C}_{i} / \mathrm{C}_{a}$ and deposition of both nitrogen and sulfur may be evidence that regulations put in place by congress have had noticeable effects on tree physiology. In an area of tree physiology that has focused primarily on the effect of rising $\mathrm{CO}_{2}$ concentrations this link may lead to investigating other possible drivers of physiological change in trees. 


\section{ACKNOWLEDGMENTS}

The author wishes to thank Dr. Richard Thomas for his mentorship and friendship through this learning experience. Thank you to Drs. Peterjohn and Hessl for their guidance in creating a plan of study and in writing this manuscript. Thank you to Kenneth Smith for all of his hard work and support in conducting this research. To Dr. Jesse Nippert, thank you for your support and encouragement as well as manuscript revision suggestions. Most of all, thank you to my wife for her love and encouragement. 


\section{TABLE OF CONTENTS}

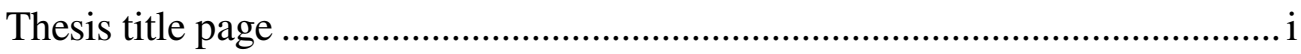

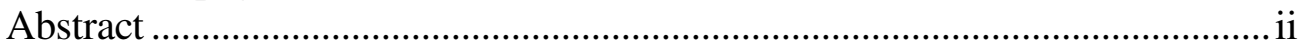

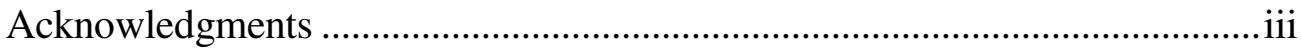

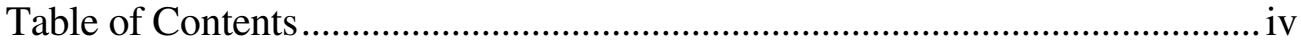

Chapter 1: General introduction ...........................................................................

Literature cited ..................................................................... 8-11

Chapter 2: Investigation of age related changes in photosynthetic capacity and hydraulic conductance of Juniperus virginiana in a cedar glade in West Virginia, US ................................................................12-30

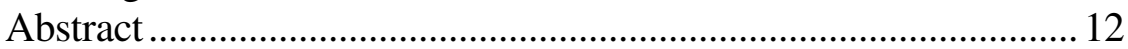

Introduction...................................................................12-13

Materials and Methods .............................................................13-16

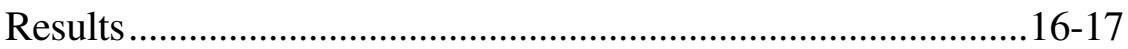

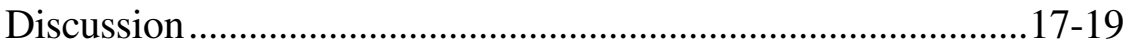

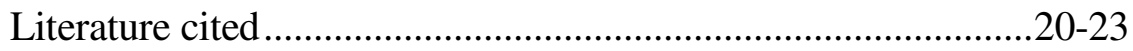

Tables and Figures...............................................................24-30

Chapter 3: Investigation of Juniperus virginiana growth during the past

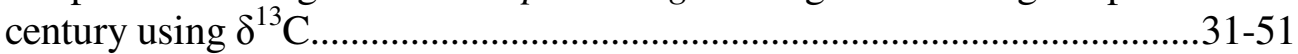

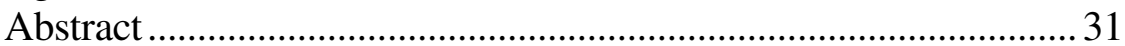

Introduction........................................................................ $31-33$

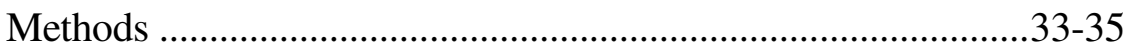

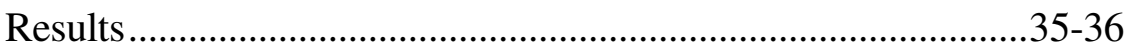

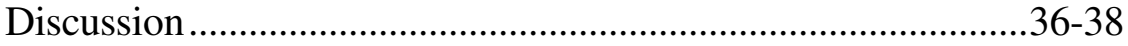

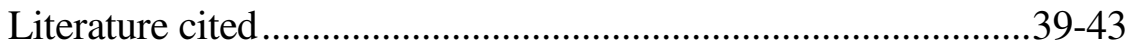

Figures...........................................................................44-51

Chapter 4: Conclusions from this study ...................................................52-53

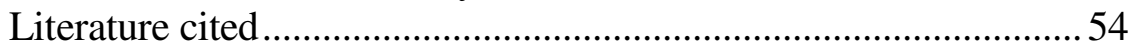




\section{CHAPTER 1: General introduction}

Forest ecosystems play a central role in the global carbon cycle; they sustain approximately $80 \%$ of terrestrial net primary production and $50 \%$ of global NPP (Whittaker 1975; Field et al. 1998) and are a major part of the terrestrial carbon sink that removes approximately $30 \%$ of anthropogenic $\mathrm{C}$ emissions each year (Canadell et al. 2007). For more accurate predictions of terrestrial C sequestration coupled biosphereatmosphere models require a mechanistic understanding of how carbon cycling in trees and forests responds to atmospheric $\mathrm{CO}_{2}$, temperature, and precipitation (Dufresne et al. 2002; Friedlingstein et al. 2006; Meehl et al. 2007). In addition, since trees and forests are not static, a greater understanding of physiological mechanisms involved with changes in forest productivity as trees and forests age is essential to our understanding of forest ecosystems (Gower et al. 1996; Ryan and Waring 1992). My thesis research used an old growth stand of Juniperus virginiana (Eastern red cedar) in the Central Appalachian Mountains of West Virginia to examine how carbon assimilation changes as they age. I performed two studies; the first examined of how tree age affects the physiological ecology of Juniperus virginiana in their native habitat; the second used the stable $\mathrm{C}$ isotopes in the annual growth rings to determine whether we could detect how climatic and environmental factors affected $\mathrm{C}$ assimilation and growth over the last century.

\section{A physiological examination of seasonal assimilation in old Juniperus virginiana trees}

Forest productivity declines as the trees in a forest age (reviews by Ryan et al. 1997; Pregitzer \& Euskirchen 2004; DeLucia et al. 2007). The reason for this decline, however, is unclear. One hypothesis is that there may be a decline in photosynthesis linked to the reduced ability to provision foliage with water, specifically a reduced stem hydraulic conductance or the ability to move water through the stem (Ryan and Yoder 1997). Several studies have examined the hydraulic limitation hypothesis, but most of these studies have used trees that are both tall and old (e.g. Koch et al. 2004) and the effects of these two factors on hydraulic conductivity may be confounded. The gravitational force exerted on the water column in xylem has been found to lower the water potential by approximately 0.01 MPa per meter (Ryan and Yoder 1997) and thus, reduced hydraulic conductance may be a consequence of tree height and not a consequence of old age. Few studies have examined the effect of tree age on hydraulic limitation independent of tree height (McDowell et al. 2002; Mencuccini et al. 2005).

My thesis project examined the physiological functioning of a chronosequence of $J$. virginiana trees that are approximately the same height $(6.77 \pm 0.54 \mathrm{~m})$ yet differ greatly in age (98 - 481 years). Measurement of hydraulic conductance and photosynthetic parameters were conducted to investigate age related declines in productivity. A chronosequence of trees in a single stand was used to reduce variability due to site differences such as slope, aspect and nutrient availability, as well as minimizing ecological factors, such as plant competition and tree height.

My assessment of productivity had three elements. First, I measured stem hydraulic conductance of J. virginiana trees with the hypothesis that hydraulic conductance will decrease with age. Second, I assessed 
the stomatal and biochemical limitations of leaf photosynthesis of these trees across two growing seasons. If the stomatal limitation of photosynthesis increases with tree age, this would provide support for the hydraulic limitation hypothesis. If biochemical limitations increase with tree age, this might indicate nutrient limitations of productivity instead of hydraulic conductance. Thus, I also measured foliar nitrogen across the tree chronosequence. The third element of my study was to use $\delta^{13} C$ of leaf material as a proxy for the relationship between water use and photosynthesis to provide an integrated index of water use efficiency (Gower et al. 1996) that links stomatal conductance over an entire year to $\mathrm{C}$ assimilation.

\section{An examination of long-term Juniperus productivity using stable isotopes in tree rings}

In order to investigate changes in productivity over the last century, I used stable isotopes of carbon $\left(\delta^{13} C\right)$ in the annual rings of the same stand of J. virginiana trees as in the previous study to examine how $\delta^{13} C$, the ratio of internal leaf $\mathrm{CO}_{2}$ concentration $\left(C_{i}\right)$ to atmospheric $\mathrm{CO}_{2}$ concentration $\left(C_{a}\right)$, and instantaneous water use efficiency changed over the last one hundred years. Correlations between these parameters and records of climate and other environmental factors will be used to determine potential explanations for patterns of stable isotopes in the chronosequence of tree rings. This site-specific analysis may indicate whether carbon isotopes make these J. virginiana trees a good candidate to use for climate reconstruction of the eastern U.S.

Photosynthesis is the physiological process regulating the incorporation of carbon into plants. In a light saturated environment photosynthesis is limited by ribulose-1,5-bisphosphate carboxylase/oxygenase activity or the efficiency of regeneration of ribulose-1,5-bisphosphate (Farquhar and von Caemmerer 1982). The link between environmental conditions and physiological response, with regards to carbon, can be determined using the equation below that calculates the fractiontion of heavy and light $\mathrm{C}$ isotopes in a sample,

$$
\Delta^{13} C=a+(b-a)\left(C_{i} / C_{a}\right)
$$

where $a$ refers to fractionation resulting from changes in diffusion through stomata, $b$ is the enzymatic discrimination during carboxylation and $C_{i} C_{a}$ refers to the ratio of the $\mathrm{CO}_{2}$ concentration inside the leaf to atmospheric $\mathrm{CO}_{2}$ concentration (Farquhar et al. 1989). These isotopic fractionations are affected by the biochemical demand for $C$ due to photosynthetic activity (Farquhar and Sharkey 1982) and stomatal conductance. Stomata are the primary regulator of water loss in plants but also have large effects on $\mathrm{CO}_{2}$ inside the leaf and, therefore, influence isotopic composition of $C$ greatly. By investigating current and past $C_{i} C_{a}$ ratios estimated from the isotopic composition of wood samples, the influence of climate and atmospheric composition on stomatal regulation can be determined. The link between assimilation of carbon and water use is investigated using water use efficiency (WUE), calculated as carbon gain per unit of water lost through transpiration. Many factors contribute to stomatal control, such as changing humidity and temperature, making interpretations of WUE from $\delta^{13} C$ difficult (Farquhar and Sharkey 1982). Understanding the relationships between the isotopic signature of plant material and the biochemical processes that relate WUE to climatic conditions can lead to better understanding of plant physiology over the life of the tree, 
climate variability and how the trees respond to other environmental factors. In this study, WUE was used to estimate the significance of stomatal changes in trees throughout the past century.

Dendrochronology has been used to analyze long-term tree response to weather variability in efforts to better understand climate variability. The use of stable isotopes of $C$ that are locked in the cellulose of wood is a valuable tool that provides an annually defined index of physiological response to climate (McCarroll and Loader 2004). The differential incorporation of heavy and light isotopes in wood is termed fractionation and is an indicator of physiological response to climate or other environmental factors. If there are direct correlations between the isotopes found in wood and weather, tree rings may be a relative index of past climate. These stable isotopic signals function primarily to give an indication of physiological functioning over time but may also provide indices of past climate variability which can be used to strengthen climate reconstructions (Spiker and Hatcher 1987; Schleser et al. 1999). The strength of using changes in stable isotopes as part of a dendrochronological reconstruction of climate is that they provide a mechanistic link between isotopic composition of wood and environmental conditions. The uses of multiple climate proxies (e.g., $\delta^{13} C$ and $\delta^{18} O$ ) may make climate reconstruction more statistically powerful and enhance the ring width climate signal (Gagen et al. 2006). While relationships between climate and isotopic signature of wood can often be found, understanding the mechanisms linking physiological responses to climate is imperative for future development of climate reconstructions. This technique is often more powerful than traditional dendrochrological reconstruction of climate (von Storch et al. 2004), but few analyses exist for eastern North America.

\section{Study site}

The study site is a stand of $J$. virginiana trees located along the South branch of the Potomac River in southern Grant County, WV, on a northwestern facing limestone outcrop located above Smoke Hole Canyon (38 $53^{\prime} 1.95^{\prime \prime} \mathrm{N} 79^{\circ} 14^{\prime} 10.05^{\prime \prime W} ; 670 \mathrm{~m}$ above sea level). This site in the Ridge and Valley Physiographic Province of northeastern West Virginia has been defined as a cedar glade (Bartgis 1993) and is approximately 0.1 hectares. The soil in this glade woodland has little organic matter and is primarily composed of broken limestone. In addition to Juniperus virginiana trees, the overstory vegetation is comprised of Quercus muhlenbergii, Quercus alba, Fraxinus Americana, and Juglans nigra, and the open overstory allows most trees receive full sunlight throughout the day. 


\section{Literature Cited}

Bartgis RL (1993) The limestone glades and barrens of West Virginia. Castanea 58: 69-89.

Bernacchi CJ, Singsaas EL, Pimentel C, Portis AR, Jr., Long SP (2001) In vivo temperature response functions for leaf steady-state photosynthesis models. Photosynthesis Research 69: 235.

Canadell JG, Le Quéré C, Raupach MR, Field CB, Buitenhuis ET, Ciais P, Conway TJ, Gillett NP, Houghton RA, Marland G (2007) Contributions to accelerating atmospheric $\mathrm{CO}_{2}$ growth from economic activity, carbon intensity, and efficiency of natural sinks. Proceedings of the National Academy of Sciences of the United States of America 104: 18866-18870.

DeLucia EH, Drake JE, Thomas RB, Gonzalez-Meler M. (2007) Forest carbon use efficiency: is respiration a constant fraction of gross primary production? Global Change Biology 13: 1157-1167.

Dufresne JL, Friedlingstein P, Berthelot M et al. (2002) On the magnitude of positive feedback between future climate change and the carbon cycle. Geophysical Research Letters, 29, 1405, doi:10.1029/2001GL013777.

Farquhar GD, Caemmerer SV, Berry JA (1980) A biochemical-model of photosynthetic $\mathrm{CO}_{2}$ assimilation in leaves of C3 species. Planta 149: 78-90.

Farquhar GD, Ehleringer JR, Hubick KT (1989) Carbon isotope discrimination and photosynthesis. Annual Review of Plant Physiology and Plant Molecular Biology 40: 503-537.

Farquhar GD, Sharkey TD (1982) Stomatal conductance and photosynthesis. Annual Review of Plant Physiology and Plant Molecular Biology 33: 317-345.

Field CB, Behrenfeld MJ, Randerson JT, Falkowski P. (1998) Primary production of the biosphere: integrating terrestrial and oceanic components. Science 281: 237-240.

Friedlingstein P, Cox P, Betts R, Bopp L, Von Bloh W, Brovkin V, Cadule P, Doney S, Eby M, Fung I, Bala G, John J, Jones C, Joos F, Kato T, Kawamiya M, Knorr W, Lindsay K, Matthews HD, Raddatz T, Rayner P, Reick C, Roeckner E, Schnitzler KG, Schnur R, Strassmann K, Weaver AJ, Yoshikawa C, Zeng N (2006) Climate-carbon cycle feedback analysis: results from the (CMIP)-M-4 model intercomparison. Journal of Climate 19: 3337-3353. 
Gagen M, McCarroll D, Edouard JL (2006) Combining ring width, density and stable carbon isotope proxies to enhance the climate signal in tree-rings: An example from the southern French Alps. Climatic Change 78: 363-379.

Gower ST, McMurtrie RE, Murty D (1996) Aboveground net primary production decline with stand age: Potential causes. Trends in Ecology \& Evolution 11: 378-382.

Harley PC, Loreto F, Dimarco G, Sharkey TD (1992) Theoretical considerations when estimating the mesophyll conductance to $\mathrm{CO}_{2}$ flux by analysis of the response of photosynthesis to $\mathrm{CO}_{2}$. Plant Physiology 98: 1429-1436.

Harley PC, Sharkey TD (1991) An improved model of C3 photosynthesis at high $\mathrm{CO}_{2}$ - reversed $\mathrm{O}_{2}$ sensitivity explained by lack of glycerate reentry into the chloroplast. Photosynthesis Research 27: 169-178.

Harley PC, Thomas RB, Reynolds JF, Strain BR (1992) Modeling photosynthesis of cotton grown in elevated $\mathrm{CO}_{2}$. Plant Cell and Environment 15: 271-282.

Herrick JD, Thomas RB (2001) No photosynthetic down-regulation in sweetgum trees (Liquidambar styraciflua $\mathrm{L}$.) after three years of $\mathrm{CO}_{2}$ enrichment at the Duke Forest FACE experiment. Plant Cell and Environment 24: 53-64.

Kame'enui A, Hagen E, Kiang J. (2005) Water supply reliability forecast for the Washington, DC metropolitan area year 2025, Rep. 05-06, Interstate Comm. on the Potomac River Basin, Rockville, Md.

Koch GW, Sillett SC, Jennings GM, Davis SD (2004) The limits to tree height. Nature 428:851-854.

Kolb KJ, Sperry JS, Lamont BB (1996) A method for measuring xylem hydraulic conductance and embolism in entire root and shoot systems. Journal of Experimental Botany 47: 1805-1810.

Leavitt SW, Danzer SR (1992) Delta ${ }^{13} \mathrm{C}$ variations in C3 plants over the past 50,000 years. Radiocarbon 34: 783-791.

Maxwell RS, Hessl AE, Cook ER, Pederson N. (2011) A multispecies tree ring reconstruction of Potomac River streamflow (950-2001). Water Resources Research. 47.

McCarroll D, Loader NJ (2004) Stable isotopes in tree rings. Quaternary Science Reviews 23: 771-801. 
McDowell NG, Phillips N, Lunch C, Bond BJ, Ryan MG (2002) An investigation of hydraulic limitation and compensation in large, old Douglas-fir trees. Tree Physiology 22: 763-774.

Medlyn BE, Badeck FW, De Pury DGG, Barton CVM, Broadmeadow M, Ceulemans R, De Angelis P, Forstreuter M, Jach ME, Kellomaki S, Laitat E, Marek M, Philippot S, Rey A, Strassemeyer J, Laitinen K, Liozon R, Portier B, Roberntz P, Wang K, Jarvis PG (1999) Effects of elevated $\left[\mathrm{CO}_{2}\right]$ on photosynthesis in European forest species: a meta-analysis of model parameters. Plant Cell and Environment 22: 1475-1495.

Meehl GA, Stocker TF, Collins WD et al. (2007) Global climate projections. In: Climate Change 2007: The Physical Science Basis. Contribution of Working Group I to the Fourth Assessment Report of the Intergovernmental Panel on Climate Change (eds Solomon S, Qin D, Manning M, Chen Z, Marquis M, Averyt KB, Tignor M, Miller HL). pp 747- 846. Cambridge University Press, Cambridge, UK.

Mencuccini M, Martinez-Vilalta J, Vanderklein D, Hamid HA, Korakaki E, Lee S, Michiels B (2005) Sizemediated ageing reduces vigor in trees. Ecology Letters 8: 1183-1190.

Pregitzer KS and Euskirchen ES (2004) Carbon cycling and storage in world forests: biome patterns related to forests age. Global Change Biology 10: 2052-2077.

Rinne KT, Boettger T, Loader NJ, Robertson I, Switsur VR, Waterhouse JS (2005) On the purification of alpha-cellulose from resinous wood for stable isotope (H, C and O) analysis. Chemical Geology 222: $75-82$.

Ryan MG, Waring RH (1992) Maintenance respiration and stand development in a sub-alpine lodgepole pine forest. Ecology 73: 2100-2108.

Ryan MG, Yoder BJ (1997) Hydraulic limits to tree height and tree growth. Bioscience 47: 235-242.

Ryan MG, Binkley D and Fownes J.H. (1997) Age-related decline in forest productivity: pattern and process. Advances in Ecological Research 27: 213-262.

Schleser GH, Frielingsdorf J, Blair A (1999) Carbon isotope behavior in wood and cellulose during artificial aging. Chemical Geology 158: 121-130. 
Sharkey TD (1985) Steady-state room-temperature fluorescence and $\mathrm{CO}_{2}$ assimilation rates in intact leaves. Photosynthesis Research 7: 163-174.

Singsaas EL, Ort DR, DeLucia EH (2000) Diurnal regulation of photosynthesis in understory saplings. New Phytologist 145: 39-49.

Sperry JS, Donnelly JR, Tyree MT (1988) A method for measuring hydraulic conductivity and embolism in xylem. Plant Cell and Environment 11: 35-40.

Spiker EC, Hatcher PG (1987) The effects of early diagenesis on the chemical and stable carbon isotopic composition of wood. Geochimica Et Cosmochimica Acta 51: 1385-1391.

Stokes MA, Smiley TL (1968) An Introduction to Tree-Ring Dating. University of Arizona Press, Tucson. (Reprinted 1995). pp 3 - 20.

Thomas RB, Lewis JD, Strain BR (1994) Effects of leaf nutrient status on photosynthetic capacity in loblollypine (Pinus taeda L.) seedlings grown in elevated atmospheric $\mathrm{CO}_{2}$. Tree Physiology 14: 947-960.

von Storch H, Zorita E, Jones JM, Dimitriev Y, Gonzalez-Rouco F, Tett SFB (2004) Reconstructing past climate from noisy data. Science 306: 679-682.

von Caemmerer S, Farquhar GD (1981) Some relationships between the biochemistry of photosynthesis and the gas-exchange of leaves. Planta 153: 376-387.

Ward JK, Harris JM, Cerling TE, Wiedenhoeft A, Lott MJ, Dearing MD, Coltrain JB, Ehleringer JR (2005) Carbon starvation in glacial trees recovered from the La Brea tar pits, southern California. Proceedings of the National Academy of Sciences of the United States of America 102: 690-694.

Whittaker RH (1975) Communities and Ecosystems, 2nd ed. MacMillan, NY. 385 pp. 
CHAPTER 2: Investigation of age related changes in Photosynthetic Capacity and Hydraulic Conductance of Juniperus virginiana in a Cedar Glade in West Virginia, US.

\begin{abstract}
Using an old-growth stand of Juniperus virginiana in the Central Appalachian Mountains of West Virginia, we examined age-related changes in both photosynthesis and hydraulic conductance on an evenheight chronosequence of trees. This stand of trees was chosen to investigate how physiological mechanisms changed over the last century as an essential part of our furthering our understanding of tree age effects on forest ecosystems. Studying forest productivity changes over time will improve our ability to understand the ecological significance of tree physiology on the global carbon cycle. We predicted that productivity would decline in trees between 98 and 481 years old, and that reductions in hydraulic conductance would be responsible for these declines. There were no significant reductions in photosynthesis, stomatal conductance, ribulose-1,5-bisphosphate carboxylase/oxygenase (rubisco) activity or electron transport in the chronosequence until three young trees $(<10$ years old) were included in the analysis. Hydraulic conductance showed a significant decline with tree age $\left(r^{2}=0.20, p=0.05\right)$ on day 279 . However, all other sampling dates showed no such relationship. The significant relationships only occurred under specific climatic conditions and were not present on all sampling dates. The data suggest that in these trees any age related decline in productivity is occurring before the trees reach 100 years of age, after which environmental conditions have more of an effect on changes in productivity than age.
\end{abstract}

\title{
Introduction
}

Forest trees are responsible for about $80 \%$ of terrestrial net primary productivity (Whittaker 1975; Field et al. 1998) and contribute to a significant portion of the terrestrial carbon sink that removes about $30 \%$ of anthropogenic carbon emissions (Canadell et al. 2007). Thus, an understanding of the ecological and physiological factors that control tree growth is important for developing models that estimate carbon cycling in forest ecosystems. One factor that requires a greater understanding is the common observation that tree productivity slows as trees become older and taller (Gower et al. 1996; Ryan and Waring 1992). Several hypotheses have been developed for why tree growth slows with age including an alteration in the balance between photosynthesis and respiration, changes in nutrient availability, and stomatal constraint leading to increased hydraulic resistance; with the hydraulic limitation hypothesis gaining the most support in the ecological community (Gower et al. 1996; Ryan and Yoder 1997). Studies examining these hypotheses have reported varied results suggesting that multiple drivers may be at play and that a species dependent examination of physiological functioning in aging trees is important in understanding NPP decline (Ryan and Waring 1992; Yoder et al. 1994; Gower et al. 1996; McDowell et al. 2002; Koch et al. 2004; Mencuccini et al. 2007). Several studies have examined the hydraulic limitation hypothesis, but most have used trees that are both tall and old making it difficult to separate the confounding effects of age and height on hydraulic conductance (Mencuccini and Grace 1996; Ryan and Yoder 1997; McDowell et al. 2002; Phillips et al. 2002; 
Barnard and Ryan 2003; Koch et al. 2004; Mencuccini et al. 2005; Yoder et al. 1994). The gravitational force exerted on the water column in xylem has been found to lower the water potential by approximately $0.01 \mathrm{MPa}$ per meter (Ryan and Yoder 1997) and thus, reduced hydraulic conductance may be a consequence of tree height and not only a consequence of old age. Few studies have examined the effect of tree age on hydraulic conductance independent of tree height (McDowell et al. 2002; Mencuccini et al. 2005).

The purpose of this study was to examine age-related declines in photosynthesis and hydraulic conductance using a chronosequence of Juniperus virginiana trees that vary greatly in age (98 - 481 years), but are similar in height (3.4 to $10.7 \mathrm{~m}$ ). We hypothesized that both assimilation and hydraulic conductance would decline as $J$. virginiana trees increased in age.

\section{Materials and Methods}

To test our hypothesis, trees from a single stand were used to help reduce variations due to differences in slope, aspect, geology, climate, and nutrient availability that are often inherent in studies that compare trees from different sites. Stem hydraulic conductance was measured on branches from the upper canopy (Kolb et al. 1996) along a tree chronosequence to determine whether water transport diminished with tree age. Light-saturated net photosynthesis versus leaf internal $\mathrm{CO}_{2}$ concentration was measured on the chronosequence to assess whether stomatal and biochemical limitations of leaf photosynthesis were affected by tree age. We hypothesized that if stomatal limitation of photosynthesis increased with tree age, this would provide support for the hydraulic limitation hypothesis due to the role of stomata in regulating water loss. Measurement of $\delta^{13} \mathrm{C}$ of current year leaf tissue, a proxy for the ratio of the $\mathrm{CO}_{2}$ concentration inside the leaf to atmospheric $\mathrm{CO}_{2}$ concentration $\left(C_{i} / C_{a}\right)$, was conducted to investigate the role stomatal control might play in changes in productivity over the life of the leaves (Farquhar et al. 1982). Nutrient limitation was investigated by comparing biochemical limitations in conjunction with decreased foliar $\mathrm{N}$ concentrations which may indicate nutrient limitation, rather than hydraulic conductance, as a driver of reductions in productivity as the tree ages.

\section{Site description and experimental design}

The study site is a stand ( 0.1 ha) of J. virginiana trees located along the South branch of the Potomac River in southern Grant County, WV, on a northwestern facing limestone outcrop above Smoke Hole Canyon (38 $53^{\prime} 1.95^{\prime \prime}$ N, 79¹4'10.05" W; $670 \mathrm{~m}$ above sea level). This site is in the Ridge and Valley Physiographic Province of northeastern West Virginia has been defined as a cedar glade (Bartgis 1993) with soil that has little organic matter and is primarily composed of broken limestone. In addition to J. virginiana trees, the overstory vegetation is comprised of Quercus muhlenbergii, Quercus alba, Fraxinus Americana, and Juglans nigra and the open overstory allows most trees to receive full sunlight throughout the day.

A transect was established running northeast to southwest and parallel to the bluff approximately $6 \mathrm{~m}$ from the edge. J. virginiana trees were cored along the transect using a 5-mm diameter tree borer and prepared using standard dendrochronology techniques (Fritts 1976). Cores were used to give approximate 
ages by counting rings and were not cross-dated due to the lack of a master chronology for the site at the time of sampling. Thus, tree age is an estimate because cores were not analyzed for false or missing rings. Using these ages, a chronosequence of 21 trees $(98-481$ years old) with even height $(6.77 \pm 0.54 \mathrm{~m})$ were selected for physiological measurements.

Precipitation events and maximum and minimum temperature during the measurement period (June to October 2008 and April to September 2009) were collected from a weather station in Cabins, WV approximately 8 miles from the site (Figure 1). Pre-dawn and mid-day water potentials were measured on all trees in our chronosequence using a Scholander Pressure Chamber (Soilmoisture Equipment Co., Santa Barbara, CA). For these measurements, small branch sections (10 $\mathrm{cm}$ in length) were collected using pole loppers from the upper canopy of the trees. Predawn measurements were taken at approximately 0500 EST and midday measurements were taken at approximately 1200 EST. At the time of mid-day measurements, soil moisture at $1-5 \mathrm{~cm}$ below the soil surface was determined using time-domain reflectometry (Hydrosense Soil Moisture Probe, Campbell Scientific, Logan, UT).

\section{Gas exchange measurements}

Gas exchange was measured on ten J. virginiana trees in the chronosequence using an open-flow gas exchange system with an attached red/blue LED light source (LI6400, Li-Cor, Inc, Lincoln, NE). Trees were chosen to have as even a distribution of ages as possible with trees determined to be 98, 112, 145, 168, 208, 228, 248, 308, 420, and 481 years old. Branches were collected in 2008 and 2009 from the upper canopy using pole loppers and immediately placed into containers filled with water (floral water picks). Foliage used for analysis was from mature leaves taken from the end of branches. Measurements were taken approximately every 30 days, May through October, between 1000 and 1600 EST on sunny days to minimize diurnal effects (Singsaas et al. 2000) with saturating light $\left(\sim 1500 \mu \mathrm{mol} \mathrm{m} \mathrm{m}^{-2} \mathrm{~s}^{-1}\right)$. The initial $\mathrm{CO}_{2}$ concentration was maintained at $380 \mu 11^{-1}$.

After an equilibration of $\sim 5$ minutes, steady-state light-saturated photosynthesis $\left(A_{\text {sat }}\right)$ and stomatal conductance $\left(g_{s}\right)$ were measured. The relationship between net photosynthetic rate $(A)$ and internal leaf $\mathrm{CO}_{2}$ concentration $\left(C_{i}\right)$ was then measured to assess the stomatal and biochemical limitations on photosynthesis (von Caemmerer and Farquhar 1981, Farquhar and Sharkey 1982, Sharkey 1985). To generate $A-C_{i}$ curves, photosynthesis was measured at ten $\mathrm{CO}_{2}$ concentrations between 50 and $1500 \mu \mathrm{CO}_{2} \mathrm{l}^{-1}$ air using the same environmental conditions used for the steady state measurements. These measurements were then used to parameterize the model of photosynthesis proposed by Farquhar et al. (1980) and subsequently modified by Harley et al. (1992) and Bernacchi et al. (2001). The model uses biochemically-based equations to describe how photosynthesis is regulated by the amount, activity and kinetic properties of ribulose-1,5-bisphosphate carboxylase/oxygenase (rubisco) $\left(V c_{\max }\right)$, and the rate of electron transport mediated through ribulose-1,5bisphosphate regeneration $\left(J_{\max }\right)$ (Harley and Sharkey 1991, Harley et al. 1992). 
Since they are temperature dependent, values of both $V c_{\max }$ and $J_{\max }$ were standardized to $25^{\circ} \mathrm{C}$ (Bernacchi $e t$ al. 2001, McMurtie and Wang 1993). Relative stomatal limitation (RSL) was calculated using,

$$
R S L=\left(1-A / A_{0}\right) \times 100
$$

where $A$ is the photosynthetic rate at ambient $\mathrm{CO}_{2}$ concentration of the atmosphere $\left(C_{a}\right)$ and $A_{0}$ is the theoretical photosynthetic rate where $C_{i}$ equals $C_{a}$, (i.e. stomatal conductance is infinite; Farquhar and Sharkey 1982).

After the gas exchange analyses, all leaves were taken to the lab and scanned to determine their projected area (Canoscan 9950F, Canon, Lake Success, NY). The projected leaf area was then multiplied by $p i$ to calculate total leaf area (Cregg 1992). Leaf samples were dried at $65^{\circ} \mathrm{C}$, and leaf mass per unit area was

calculated $\left(\mathrm{LM}_{\text {area }}, \mathrm{g} \mathrm{m}^{-2}\right)$ by dividing mass by total leaf area. Once leaf mass was measured the leaves were ground to a fine powder and foliar $\mathrm{N}$ was measured using Dumas combustion (Carlo Erba NCS elemental analyzer, Fisons Instruments, Milan, Italy).

In 2009, an additional 2-3 trees that were $~ 10$ years old were sampled in a pasture approximately one kilometer from the study transect. These trees were used to compare photosynthetic capacity of J. virginiana trees of the cedar glade chronosequence to younger trees since no trees younger than 98 years old could be found in the cedar glade study site.

\section{Hydraulic Conductance}

Stem hydraulic conductance $\left(\mathrm{k}_{\mathrm{n}}\right)$ was measured using the method of Kolb et al. (1996) which was designed for highly branched stems like those found in J. virginiana. This method was adapted from Sperry et al. (1988) where hydraulic conductance is measured as a percentage of maximum water flow through the stem. In 2008, short-branched stems ( $20 \mathrm{~cm})$ from each tree of our chronosequence were cut from the upper canopy, placed in plastic bags with the cut end of stem being placed in a floral water pick, and kept on ice until returning to the lab. Hydraulic conductance was measured within three days of cutting the stems. Stems were re-cut under water and placed into a vacuum chamber with a hose attached to the cut end. The branch was subjected to an increasing vacuum to mimic the tension placed on the water column during transpiration. The flow of water through the tube was measure at $15 \mathrm{~s}$ intervals. These flow rates were plotted and the slope of the line was defined as the total stem hydraulic conductance $\left(k_{n}\right)$.

\section{Stable isotope analysis}

Leaves that were used in gas exchange analysis in 2008 were collected and a subsample of leaf material from each tree was analyzed for $\delta^{13} C$ with a ThermoFinnigan Conflow III interface and Finnigan Delta-plus Continuous Flow Stable Isotope Ratio Mass Spectrometer (Stable Isotope Mass Spectrometry Laboratory, Kansas State University, Manhattan, KS) using PeeDee River belemnite (PDB) as the reference. 
Samples had a with-in run variation of $0.07 \%$ and laboratory standards had a variation of $<0.04 \%$. Carbon isotope discrimination $\left(\Delta^{13} \mathrm{C}\right)$ was calculated according to (Farquhar et al. 1982) using,

$$
\Delta^{13} C=\left(\frac{\delta^{13} C_{a i r}-\delta^{13} C_{\text {leaf }}}{1000-\delta^{13} C_{\text {leaf }}}\right) x 1000
$$

where $\delta^{13} \mathrm{C}_{\text {leaf }}$ were isotopic values of the most recent leaf material and $\delta^{13} \mathrm{C}_{\text {air }}$ values were atmospheric values (McCarroll and Loader 2004). The $\mathrm{C}_{\mathrm{i}} / \mathrm{C}_{\mathrm{a}}$ ratio was calculated according to Farquhar et al. (1982) using,

$$
C_{i} / C_{a}=\frac{\Delta-a}{b-a}
$$

where $a$ is the fractionation constant due to diffusion of $\mathrm{CO}_{2}$ through the stomatal aperture (4.4\%o, O'Leary $1981)$ and $b$ is the fractionation constant due to rubisco (27\%, Farquhar and Richards 1984).

Data analysis

The effects of tree age on photosynthetic capacity and stem hydraulic conductance were examined two ways. First, regression analysis was used for each measurement date to determine whether tree age correlated with any of the measured physiological parameters (JMP, Statistical Analysis Systems, Cary, NC). This analysis was conducted for each growing season. An additional regression analysis included values from the 10 year-old trees from the nearby field to determine if an age effect may have occurred before trees reached an age of 98 years - the youngest age of the trees in the cedar glade chronosequence. The second way the data were examined was through the use of a one-way analysis of variance (ANOVA) model that included the effects of measurement date in a growing season on $k_{n}$, light-saturated photosynthesis, $V c_{\max }, J_{\max }$ and RSL (JMP, Statistical Analysis Systems, Cary, NC).

\section{Results}

Monthly measurements made at our site were made under a variety of environmental conditions that are important to consider when analyzing the results (Figure 1 and Table 1). Water potential and soil moisture measurements were made to assess water availability at the site. Pre-dawn water potentials of $J$. virginiana in the early part of the season (days 179 and 207) of 2008 were $47 \%$ more negative than later in the season (days 245 and 279) $(\mathrm{F}=42.1978, \mathrm{p}<0.0001$; Table 1). Mid-day water potentials were less negative on day 207 of 2008 than the other measurement days in that year $(\mathrm{F}=13.2757, \mathrm{p}<0.0001)$. Soil moisture on day 207 in 2008 was significantly drier than the other days of that field season $(F=10.7462, p<0.0001)$. Predawn water potentials in 2009 were different on all days that this parameter was measured $(\mathrm{F}=957.92, \mathrm{p}<$ 0.0001); measurements were not made on the first two sampling dates (days 115 and 151) due to rainy weather and are assumed to be very close to zero. Mid-day water potential values on day 243 of 2009 were significantly more negative than other sampling dates $(\mathrm{F}=83.42, \mathrm{p}<0.0001)$ and both mid-day and pre-dawn water potentials indicate a drier than normal period for the J. virginiana stand on day 243 of 2009. 
There was little evidence that photosynthetic capacity was related to tree age over the J. virginiana chronosequence during 2008 or 2009 (Table 2). The only age-related trend that was observed was in 2008 when there was an increase in $V_{c \max }$ with tree age on day $207\left(\mathrm{r}^{2}=0.44, \mathrm{p}=0.03\right)$. When young trees from a nearby pasture were included in the age analysis, there are reductions in $A$ and $g_{s}$ with tree age on days 181 (A: $\left.r^{2}=0.37, p=0.03 ; g_{s}: r^{2}=0.40, p=0.02\right)$ and $206\left(A: r^{2}=0.47, p=0.01 ; g_{s}: r^{2}=0.45, p=0.01\right)$. There was also a reduction in $J_{\max }$ with age on day $206\left(\mathrm{r}^{2}=0.40, \mathrm{p}=0.02\right)$.

Stem hydraulic conductance $\left(k_{n}\right)$ was not related to tree age of $J$. virginiana when analyzed over the entire growing season. When each sampling date was analyzed independently, there was a trend for a negative relationship between stem hydraulic conductance and tree age on every day except day 245 (Figure 2). There was a significant negative correlation between hydraulic conductance and tree age on day $279\left(\mathrm{r}^{2}=\right.$ $0.20, \mathrm{p}=0.05)$.

Parameters related to photosynthetic capacity varied across the season for this $J$. virginiana chronosequence in both 2008 and 2009 and were influenced by recent precipitation events. (Figure 3 2008: $A_{\text {sat }}, \mathrm{F}=8.4001, \mathrm{p}=0.0003 ; g_{s}, \mathrm{~F}=7.9615, \mathrm{p}=0.0004 ; V c_{\max }, \mathrm{F}=4.3062, \mathrm{p}=0.0116 ; J_{\max }, \mathrm{F}=9.5633, \mathrm{p}=$ 0.0001; RSL, $\mathrm{F}=4.7526, \mathrm{p}=0.0075$; Figure 4 2009: $A_{\text {sat }}, \mathrm{F}=9.0349, \mathrm{p}<0.0001 ; g_{s}, \mathrm{~F}=14.3995, \mathrm{p}<0.0001$; $\left.J_{\max }, \mathrm{F}=7.0824, \mathrm{p}<0.0001, R S L, \mathrm{~F}=4.0589, \mathrm{p}<0.0034\right)$.

Leaf $\delta^{13} C$ of $J$. virginiana in 2008 showed a significant relationship with tree age, becoming less negative with age $\left(\mathrm{r}^{2}=0.20, \mathrm{p}=0.004\right)$ (Figure 6). The $C_{i} / C_{a}$ ratio did not show a relationship with tree age over either year. The relative stomatal limitation $(R S L)$ estimated from gas exchange analysis for 2008 and 2009 was not related to tree age, although when the 2009 values for the young trees were included there was a significant increase with tree age $\left(r^{2}=0.14, \mathrm{p}=0.0009\right)$.

Leaf nitrogen concentration per unit mass and leaf mass per unit area $\left(\mathrm{LM}_{\mathrm{a}}\right)$ of $J$. virginiana showed opposing trends with tree age (Figure 6). Foliar $\mathrm{N}$ declined with tree age in $2008\left(\mathrm{r}^{2}=0.15, \mathrm{p}=0.02\right)$ but showed no effects of tree age in 2009 , even when foliar $\mathrm{N}$ concentrations from the 10 year-old trees were added to the analysis. On the other hand, leaf nitrogen per unit area was not affected by tree age in 2008, and increased with tree age in $2009\left(r^{2}=0.26, p<0.0001\right)$.

\section{Discussion}

This study examined an important, and long-standing, question in forest ecology -What causes net primary productivity to decline with tree age? (Ryan et al. 1997, Pregitzer and Euskirchen 2004, DeLucia et al. 2007). There are two prominent hypotheses that attempt to answer this question, and both were tested. The first is the hydraulic limitation hypothesis (HLH) which predicts that as trees age and grow taller stomata close to prevent xylem cavitation resulting in a decline in canopy photosynthesis (Ryan et al. 2006). More specifically it predicts that both stem hydraulic conductance and leaf photosynthesis should decrease with tree age (Ryan et al. 2006). The second hypothesis is the nitrogen limitation hypothesis (Bond 2000) which suggests that declines in nitrogen availability with stand age may result in reductions in forest productivity. 
This study, using $J$. virginiana trees that are approximately the same height $(6.77 \pm 0.54 \mathrm{~m})$ yet differ greatly in age (98- 481 years), provides little evidence to support the HLH or nitrogen limitation hypotheses. With respect to the HLH hypothesis, measurements of stem hydraulic conductance of J. virginiana on four occasions during 2008 growing season found only one sampling date (day 279) when there was a significant relationship between stem hydraulic conductance and tree age (Figure 2). Even on that day, only 20\% of variation in hydraulic conductance could be explained by tree age (Figure 2). Compared to other studies using the same method to measure hydraulic conductance (Kolb et al. 1996; Kolb et al. 1999); J. virginiana had very low values of stem hydraulic conductance regardless of tree age in the chronosequence. Since stem hydraulic conductance is not known for young J. virginiana trees it may be that an age-related effect has occurred before J. virginiana reaches the age of trees in the cedar glade stand we studied.

As a second test of the HLC hypothesis we measured parameters related to photosynthetic capacity, including light-saturated photosynthesis, stomatal conductance, and gas exchange-derived estimates of rubisco activity and electron transport capacity but found very few consistent effects of age across the chronosequence (Figure 3). Reductions in photosynthesis in aging stands of trees often occur at a younger age than trees in the J. virginiana stand (Yoder et al. 1994; Ryan et al. 2004; Drake et al. 2011). However, adding young $J$. virginiana trees ( $\leq 10$ years old \& from nearby pasture) to this analysis increased the significance of the relationship between photosynthetic capacity and tree age for only a few dates (Figure 3), which suggests that age may have little influence on photosynthesis of $J$. virginiana at this site. Net photosynthetic rates for $J$. virginiana in this cedar glade stand are similar to those found in previous studies (Lassoie et al. 1983), especially when J. virginiana is grown under water stress (Eggemeyer et al. 2006; Bihmidine et al. 2010, Volder et al. 2010), as might be expected on a rock outcrop, such as this cedar glade in West Virginia. These data imply that this species develops physiological traits to deal with water stress early in life and maintain low photosynthetic rates but a positive carbon balance and slow growth over decades or even centuries.

A third test of the HLC investigated thefoliar $\delta^{13} C$ values as an index of stomatal control over the life of leaf tissue. Measurements of foliar $\delta^{13} C$ across the $J$. virginiana chronosequence followed this predicted trend (Figure 5), which suggests that stomatal conductance of J. virginiana integrated across the life of the tissue was lower in leaves of older trees. Thus, these data support the hydraulic limitation hypothesis and are similar to decreased carbon isotope discrimination that has been observed across chronosequences of Douglas fir (McDowell et al 2002) and loblolly pine stands (Drake et al. 2011). The same trend has been observed with increasing height in giant redwood trees (Koch et al. 2004). It must be noted, however, that many other factors affect foliar $\delta^{13} C$ in the same manner as increased hydraulic conductance. For example, $\delta^{13} \mathrm{C}$ may increase with decreasing air humidity (Panak and Waring 1997), decreasing soil moisture (Korol et al. 1999), increasing irradiance (Zimmerman and Ehleringer 1990) and increasing atmospheric $\mathrm{CO}_{2}$ (Sternberg et al. 1989). Because isotopic measurements were conducted on a single stand of trees growing in a cedar glade rock outcrop, most confounding sources of environmental variation that might affect $\delta^{13} C$ were minimized. On the other hand, one potential confounding source of variation that might have affected the $\delta^{13} \mathrm{C}$ of $J$. virginiana foliage is the positive correlation between $\delta^{13} \mathrm{C}$ and leaf mass per unit area $(\mathrm{p}<0.0448$, 
$\mathrm{r}^{2}=0.11$; data not shown). In addition, this study shows that leaf mass per unit area increased as tree age of $J$. virginiana increased in the cedar glade chronosequence (Figure 6). Leaf thickness affects the conductance of $\mathrm{CO}_{2}$ from the substomatal cavity inside the leaf to the site of carboxylation in the chloroplast and leaf thickness related mesophyll conductance can have the same effect on $\delta^{13} \mathrm{C}$ as increased hydraulic conductance (Hanba et al. 1999).

An alternative hypothesis that has been proposed for reduced photosynthesis in trees as they age is that nitrogen limitation becomes exacerbated as forests age (Bond 2000). Data from this study show small but significant reductions in foliar $\mathrm{N}$ of $J$. virginiana as they age in this chronosequence for leaf samples taken in 2008, but no effect of age on foliar N in 2009 (Figure 6). Since light-saturated photosynthesis was not affected by tree age in either year, $\mathrm{N}$ reductions in 2008 with tree age may be related to some leaf function other than photosynthesis.

Whether changes in hydraulic conductance, nutrient limitation, or height are the causal factors for age-related changes in the physiology of trees that result in reductions in forest productivity is still unclear (Ryan and Yoder 1997; Mencuccini et al. 2005; Ryan 2006). This study provided little evidence that age as a single factor strongly affects leaf photosynthesis or hydraulic conductivity of stems or leaves. For these trees, current environmental conditions are far more indicative of physiological functioning than age. While $\delta^{13} \mathrm{C}$ increases over tree age as predicted by the hydraulic limitation hypothesis, there are other factors, such as leaf thickness, that may be contributing to this response. It may be that age-related changes in the physiology of $J$. virginiana occurs earlier than the youngest ages of trees in this stand, but photosynthetic rates of young $J$. virginiana in a nearby pasture were not much different than that found in this old stand in the cedar glade. 


\section{Literature cited}

Barnard HR, Ryan MG (2003) A test of the hydraulic limitation hypothesis in fast-growing Eucalyptus saligna. Plant Cell and Environment 26:1235-1245.

Bartgis RL (1993) The limestone glades and barrens of West Virginia. Castanea 58: 69-89.

Bernacchi CJ, Singsaas EL, Pimentel C, Portis AR Jr, Long SP (2001) Improved temperature response functions for models of Rubiso-limited photosynthesis. Plant, Cell and Environment 24: 253-259.

Bihmidine S, Bryan NM, Payne KR, Parde MR, Okalebo JA, Cooperstein SE, Awada T (2010) Photosynthetic performance of invasive Pinus ponderosa and Juniperus virginiana seedlings under gradual soil water depletion. Plant Biology 12: 668-675.

Bond BJ (2000) Age-related changes in photosynthesis of woody plants. Trends in Plant Science 5: 349-353.

Canadell JG, Le Quere C, Raupach MR, Field CB, Buitenhuis ET, Ciais P, Conway TJ, Gillett NP, Houghton RA, Marland $\mathrm{G}$ (2007) Contributions to accelerating atmospheric $\mathrm{CO}_{2}$ growth from economic activity, carbon intensity, and efficiency of natural sinks. Proceedings of the National Academy of Sciences of the United States of America 104: 18866-18870.

Cregg BM (1992) Leaf-area estimation of mature foliage of Juniperus. Forest Science 38: 61-67.

DeLucia EH, Drake JE, Thomas RB, Gonzalez-Meler M (2007) Forest carbon use efficiency: is respiration a constant fraction of gross primary production? Global Change Biology 13: 1157-1167.

Drake JE, Davis SC, Raetz LM, and DeLucia EH (2011) Mechanisms of age-related changes in forest production: the influence of physiological and successional changes. Global Change Biology 17: $1522-1535$.

Eggemeyer KD, Awada T, Wedin DA, Harvey FE, Zhou XH (2006) Ecophysiology of two native invasive woody species and two dominant warm-season grasses in the semiarid grasslands of the Nebraska Sandhills. International Journal of Plant Sciences 167: 991-999.

Farquhar GD, Caemmerer SV, Berry JA (1980) A biochemical-model of photosynthetic $\mathrm{CO}_{2}$ assimilation in leaves of C3 species. Planta 149: 78-90.

Farquhar GD, Sharkey TD (1982) Stomatal conductance and photosynthesis. Annual Review of Plant Physiology and Plant Molecular Biology 33: 317-345.

Farquhar GD, O'Leary MH and Berry, JA (1982) On the relationship between carbon isotope discrimination and the intercellular carbon dioxide concentration in leaves. Aust. J. Plant Physiol. 9: 121-137.

Farquhar GD, Richards RA. (1984) Isotopic composition of plant carbon correlates with water-use efficiency of wheat genotypes. Australian Journal of Plant Physiology 11: 539-552. 
Field CB, Behrenfeld MJ, Randerson JT, Falkowski P (1998) Primary production of the biosphere: integrating terrestrial and oceanic components. Science 281: 237-240.

Fritts HC (1976) Tree rings and climate. London, New York and San Francisco: Academic Press.

Gower ST, McMurtrie RE, Murty D (1996) Aboveground net primary production decline with stand age: potential causes. Trends in Ecology \& Evolution 11:378-382.

Hanba YT, Miyazawa S-I, Terashima I (1999) The influence of leaf thickness on the $\mathrm{CO}_{2}$ transfer conductance and leaf stable carbon isotope ratio for some evergreen tree species in Japanese warm temperate forests. Functional Ecology 13: 632-639.

Harley PC, Sharkey TD (1991) An improved model of $\mathrm{C} 3$ photosynthesis at high $\mathrm{CO}_{2}$ - reversed $\mathrm{O}_{2}$ sensitivity explained by lack of glycerate reentry into the chloroplast. Photosynthesis Research 27:169-178.

Harley PC, Loreto F, Dimarco G, Sharkey TD (1992) Theoretical considerations when estimating the mesophyll conductance to $\mathrm{CO}_{2}$ flux by analysis of the response of photosynthesis to $\mathrm{CO}_{2}$. Plant Physiology 98:1429-1436.

Harley PC, Thomas RB, Reynolds JF, Strain BR (1992) Modeling photosynthesis of cotton grown in elevated $\mathrm{CO}_{2}$. Plant Cell and Environment 15: 271-282.

Irvine J, Law BE, Anthoni PM, Meinzer FC (2002) Water limitations to carbon exchange in old-growth and young ponderosa pine stands. Tree Physiology 22:189-196.

Irvine J, Law BE, Kurpius MR, Anthoni PM, Moore D, Schwarz PA (2004) Age-related changes in ecosystem structure and function and effects on water and carbon exchange in ponderosa pine. Tree Physiology 24: 753-763.

Koch GW, Sillett SC, Jennings GM, Davis SD (2004) The limits to tree height. Nature 428: 851-854.

Kolb KJ, Sperry JS, Lamont BB (1996) A method for measuring xylem hydraulic conductance and embolism in entire root and shoot systems. Journal of Experimental Botany 47:1805-1810.

Kolb KJ, Sperry JS (1999) Transport constraints on water use by the Great Basin shrub, Artemisia tridentata. Plant Cell and Environment 22: 925-935.

Korol RL, Kirshbaum MUF, Farquhar GD, Jeffreys M (1999) Effects of water status and soil fertility on the C-isotope signature in Pinus radiata. Tree Physiology 19: 551-562.

Lassoie JP, Dougherty PM, Reich PB, Hinckley TM, Metcalf CM, Dina SJ. (1983) Ecophysiological investigations of understory eastern red cedar in central Missouri. Ecology 64: 1355-1366.

McCarroll D, Loader NJ (2004) Stable isotopes in tree rings. Quaternary Science Reviews 23:771-801.

McDowell NG, Phillips N, Lunch C, Bond BJ, Ryan MG (2002) An investigation of hydraulic limitation and compensation in large, old Douglas-fir trees. Tree Physiology 22: 763-774. 
McMurtrie RE, Wang, Y-P (1993) Mathematical models of the photosynthetic response of tree stands to rising $\mathrm{CO}_{2}$ concentrations and temperatures. Plant, Cell and Environment 16: 1-13.

Mencuccini M, Grace J (1996) Developmental patterns of above-ground hydraulic conductance in a Scots pine (Pinus sylvestris L) age sequence. Plant Cell and Environment 19:939-948.

Mencuccini M, Martinez-Vilalta J, Vanderklein D, Hamid HA, Korakaki E, Lee S, Michiels B (2005) Sizemediated ageing reduces vigour in trees. Ecology Letters 8:1183-1190.

O’Leary MH (1981) Carbon isotope fractionation in plants. Phytochemistry 20:553-67

Panek JA, Waring RH (1997) Stable carbon isotopes as indicators of limitations to forest growth imposed by climate stress. Ecological Applications 7: 854-683.

Phillips N, Bond BJ, McDowell NG, Ryan MG (2002) Canopy and hydraulic conductance 12 in young, mature and old Douglas-fir trees. Tree physiology 22: 205-211.

Pregitzer KS, Euskirchen ES (2004) Carbon cycling and storage in world forests: biome patterns related to forests age. Global Change Biology 10: 2052-2077.

Ryan MG, Waring RH (1992) Maintenance respiration and stand development in a sub-alpine lodgepole pine forest. Ecology 73: 2100-2108.

Ryan MG, Binkley D, Fownes JH (1997) Age-related decline in forest productivity: pattern and process. Advances in Ecological Research 27: 213-262.

Ryan MG, Yoder BJ (1997) Hydraulic limits to tree height and tree growth. Bioscience 47:235-242.

Ryan MG, Binkley D, Fownes JH, Giardina CP, Senock RS (2004) An experimental test of the causes of forest growth decline with stand age. Ecological Monographs 74: 393-414.

Ryan MG, Phillips N, Bond BJ (2006) The hydraulic limitation hypothesis revisited. Plant, Cell and Environment 29: 367-381.

Sharkey TD (1985) Photosynthesis in intact leaves of $C_{3}$ plants: Physics, physiology and rate limitations. The Botanical Review 51: 53-105.

Sperry JS, Donnelly JR, Tyree MT (1988) A method for measuring hydraulic conductivity and embolism in xylem. Plant Cell and Environment 11:35-40.

Sternberg LDL, Mulkey SS, Wright SJ (1989) Ecological interpretation of leaf carbon isotope ratios: influence of respired carbon dioxide. Ecology 70: 1317-24.

Whittaker R H (1975) Communities and Ecosystems, $2^{\text {nd }}$ ed. MacMillan, NY. 385 pp.

Volder A, Tjoelker MG, Briske DD (2010) Contrasting physiological responsiveness of establishing trees and 
a $\mathrm{C} 4$ grass to rainfall events, intensified summer drought, and warming in oak savanna. Global Change Biology 16: 3349-3362.

von Caemmerer S, Farquhar GD (1981) Some relationships between the biochemistry of photosynthesis and the gas-exchange of leaves. Planta 153: 376-387.

Wilson CJ, Manos PS, Jackson RB (2008) Hydraulic traits are influenced by phylogenetic history in the drought-resistant, invasive genus Juniperus (Cupressaceae). American Journal of Botany 95: 299314.

Yoder BJ, Ryan MG, Waring RH, Schoettle AW, Kaufmann MR (1994) Evidence of reduced photosynthetic rates in old trees. Forest Science 40: 513-527.

Zimmerman JK, Ehleringer JR (1990) Carbon isotope ratios are correlated with irradiance levels in the Panamanian orchid Catasetum viridiflavum. Oecologia 83: 247-249. 
Table 1. Site conditions for the 2008 and 2009 growing seasons. Water potential and soil moisture were measured on 17-21 trees. Air temperature was from Cabins, WV weather station (located 8 miles from the study site). 2009 measurements were on 10 of the original 21 trees and soil moisture was not recorded. Predawn water potential on days 115 and 151 in 2009 were not recorded due to inclement weather. Leaf temperatures were recorded with the LI-COR 6400 during gas exchange measurements. Precipitation is the total amount received a week prior to measurements as recorded by the weather station at Cabins, WV (N $38^{\circ}$ 59’ 48” W 79॰ 12' 29”). All values are means ( \pm 1 SE) except precipitation totals.

\begin{tabular}{|c|c|c|c|c|c|c|}
\hline $\begin{array}{l}\text { Julian } \\
\text { Day } \\
2008\end{array}$ & $\begin{array}{c}\text { Pre-dawn } \\
\text { (Mpa) }\end{array}$ & $\begin{array}{c}\text { Mid-day } \\
\text { (Mpa) }\end{array}$ & $\begin{array}{c}\text { Soil } \\
\text { Moisture \% }\end{array}$ & $\begin{array}{c}\text { Air } \\
\text { Temperature } \\
{ }^{\circ} \mathbf{C}\end{array}$ & $\begin{array}{c}\text { Leaf } \\
\text { Temperature } \\
{ }^{\circ} \mathbf{C}\end{array}$ & $\begin{array}{l}\text { Precipitation } \\
(\mathrm{mm})\end{array}$ \\
\hline 177 & $-0.97(0.04)$ & $-1.50(0.04)$ & $12.82(0.83)$ & $23.12(0.45)$ & $23.12(0.45)$ & 66.80 \\
\hline 207 & $-0.92(0.04)$ & $-0.91(0.04)$ & $9.13(0.42)$ & $21.50(1.25)$ & $21.50(1.25)$ & 29.46 \\
\hline 245 & $-0.57(0.02)$ & $-1.43(0.10)$ & $14.35(0.98)$ & $19.50(0.88)$ & $19.50(0.88)$ & 55.88 \\
\hline 279 & $-0.57(0.01)$ & $-1.50(0.06)$ & $14.37(0.79)$ & $19.90(1.81)$ & $17.90(1.81)$ & 39.37 \\
\hline \multicolumn{7}{|l|}{$\begin{array}{c}\text { Julian } \\
\text { Day } \\
2009 \\
\end{array}$} \\
\hline 115 & - & $-2.05(0.13)$ & - & $32.66(0.28)$ & $32.79(0.91)$ & 62.48 \\
\hline 151 & - & $-1.31(0.04)$ & - & $23.72(0.23)$ & $23.20(0.57)$ & 38.86 \\
\hline 181 & $-0.65(0.02)$ & $-1.99(0.05)$ & - & $25.16(0.35)$ & $24.92(0.18)$ & 18.54 \\
\hline 206 & $-1.47(0.05)$ & $-2.26(0.06)$ & - & $29.17(0.70)$ & $30.75(0.53)$ & 41.40 \\
\hline 243 & $-2.99(0.04)$ & $-3.12(0.02)$ & - & $18.92(0.54)$ & $18.19(0.32)$ & 20.32 \\
\hline 274 & $-0.84(0.03)$ & $-1.58(0.06)$ & - & $27.14(0.16)$ & $23.05(0.46)$ & 22.35 \\
\hline
\end{tabular}


Table 2. $\mathrm{P}$ values and $\mathrm{r}^{2}$ of regressions between age of Juniperus virginiana trees and light-saturated photosynthesis $\left(A_{s a t}\right)$, stomatal conductance $\left(g_{s}\right)$, carboxylation $\left(V c_{\text {max }}\right)$, electron transport $\left(J_{\text {max }}\right)$ and relative stomatal limitation $(R S L)$. Regression analyses were conducted in both 2008 and 2009. All measurements were made in saturating light of $1500 \mu \mathrm{mol} \mathrm{m} \mathrm{s}^{-1}$ and $380 \mu \mathrm{CO}_{2} \mathrm{l}^{-1}$ air with $\mathrm{n}=11$ for 2008 (except $\mathrm{n}=3$ for day 177) and $n=10$ in 2009. $P$ values and $r^{2}$ of regressions in $2009 *$ included three 10 year-old trees from a near-by pasture. $\mathrm{P}$ values with $n s$ denote a non-significant relationship between the photosynthetic parameter and tree age of Juniperus.

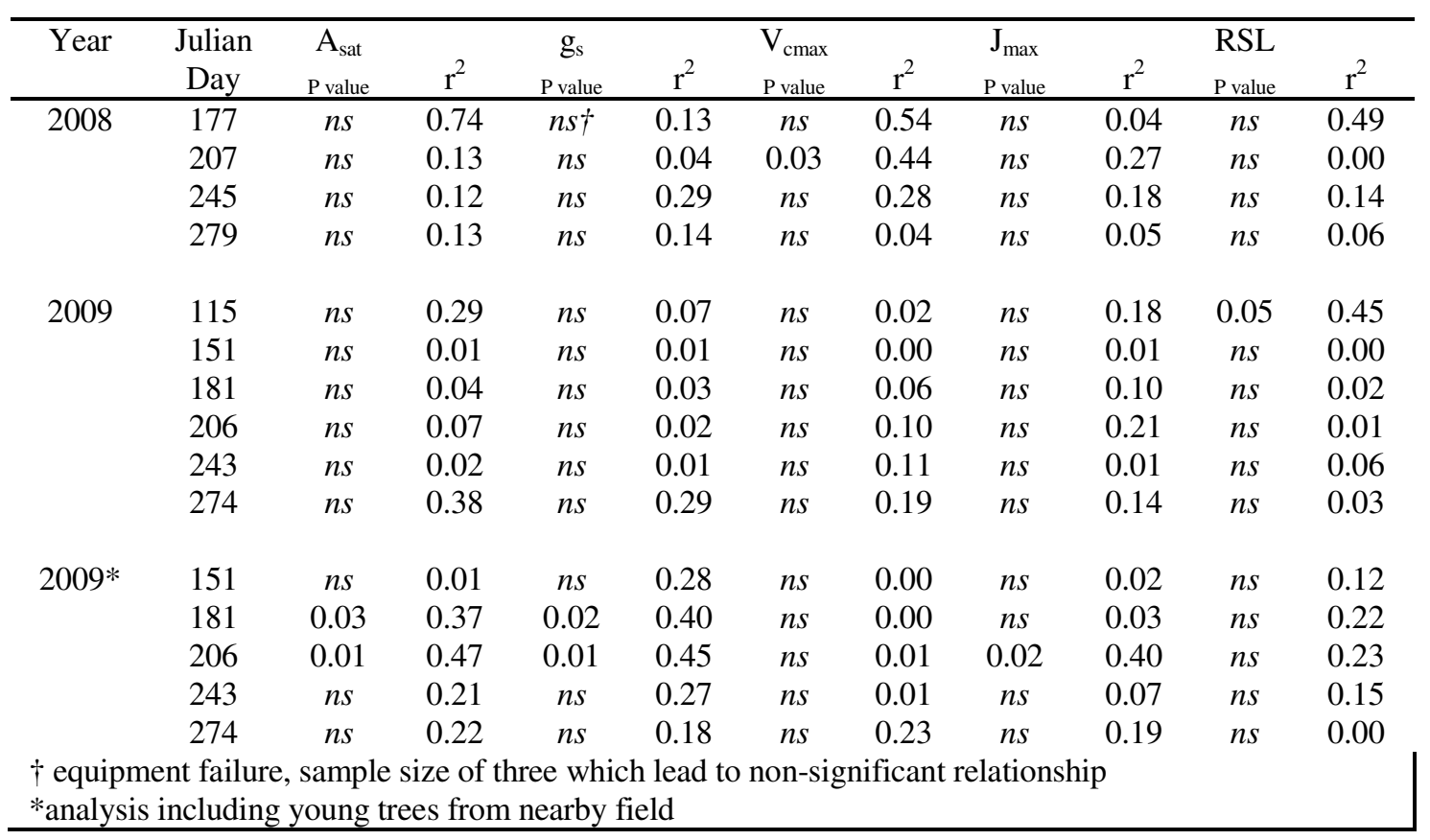



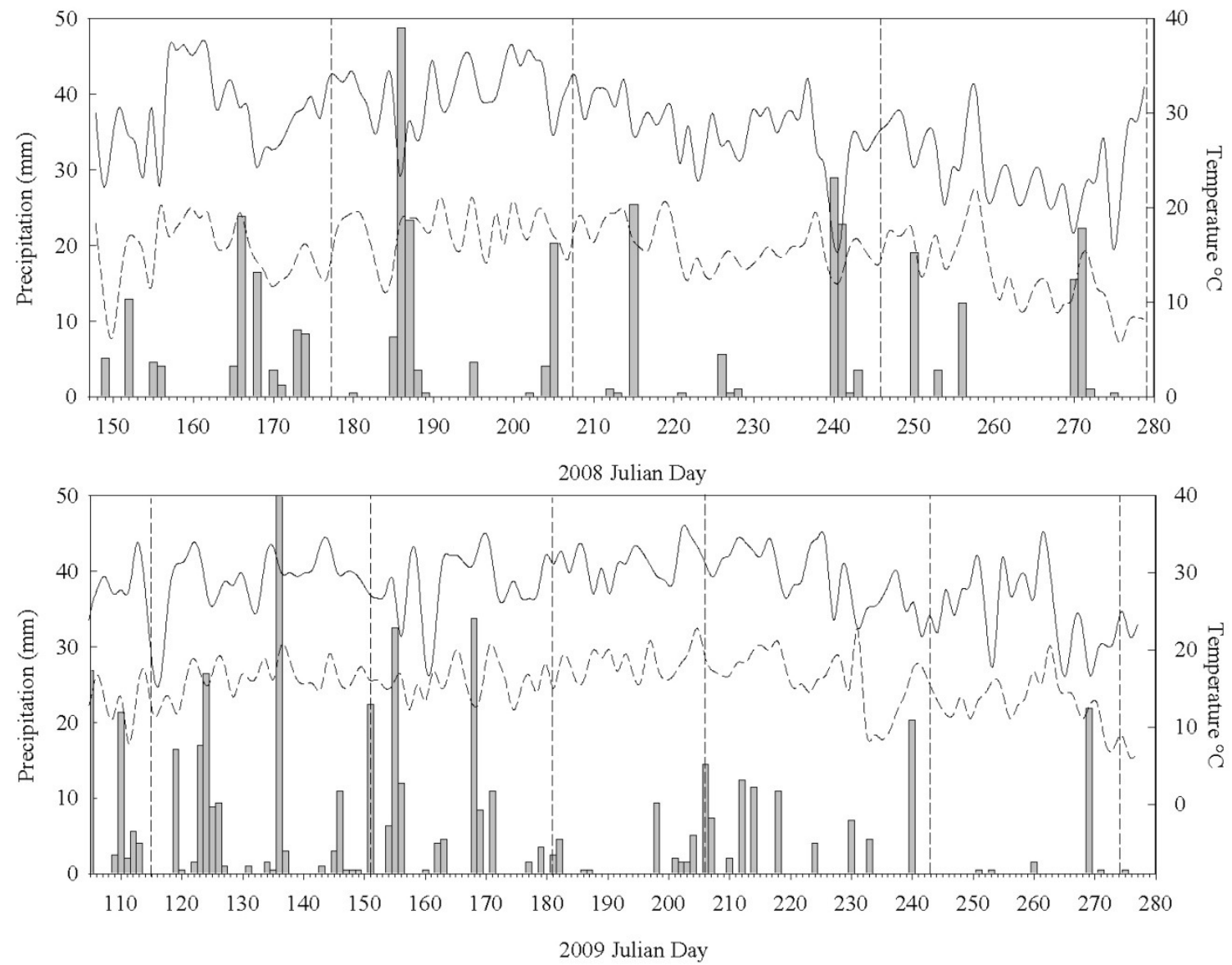

Figure 1. Maximum (-) and minimum (---) temperature and precipitation (bars) during the study period used for comparison to the physiological data. Temperature and precipitation data were collected from Cabins, WV (N 38 59' 48”, W $79^{\circ} 12^{\prime} 29^{\prime \prime}$ ) approximately 8 miles north of the site. Vertical dashed lines indicate Julian dates that physiological sampling of Juniperus virginiana trees was conducted: 177, 207, 245, 279 of 2008 and 115, 151, 181, 206, 143, 274 of 2009. 


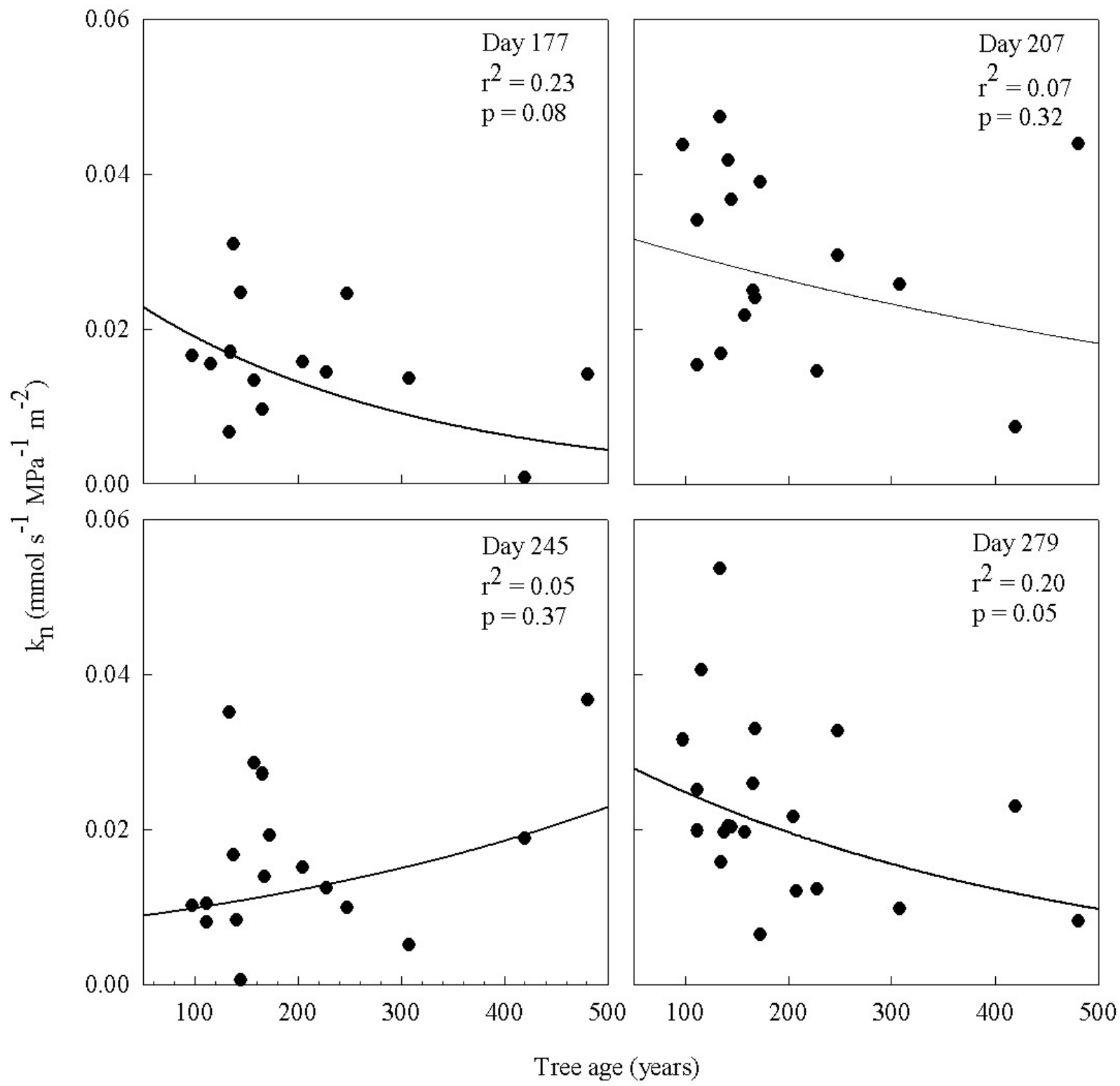

Figure 2. Stem hydraulic conductance $\left(\mathrm{k}_{\mathrm{n}}\right)$ of Juniperus virginiana measured across the 2008 growing season plotted against the ages of the individual trees. Lines are best fit using natural $\log$ transformed values of $k_{n}$ $(n=16-21)$. 

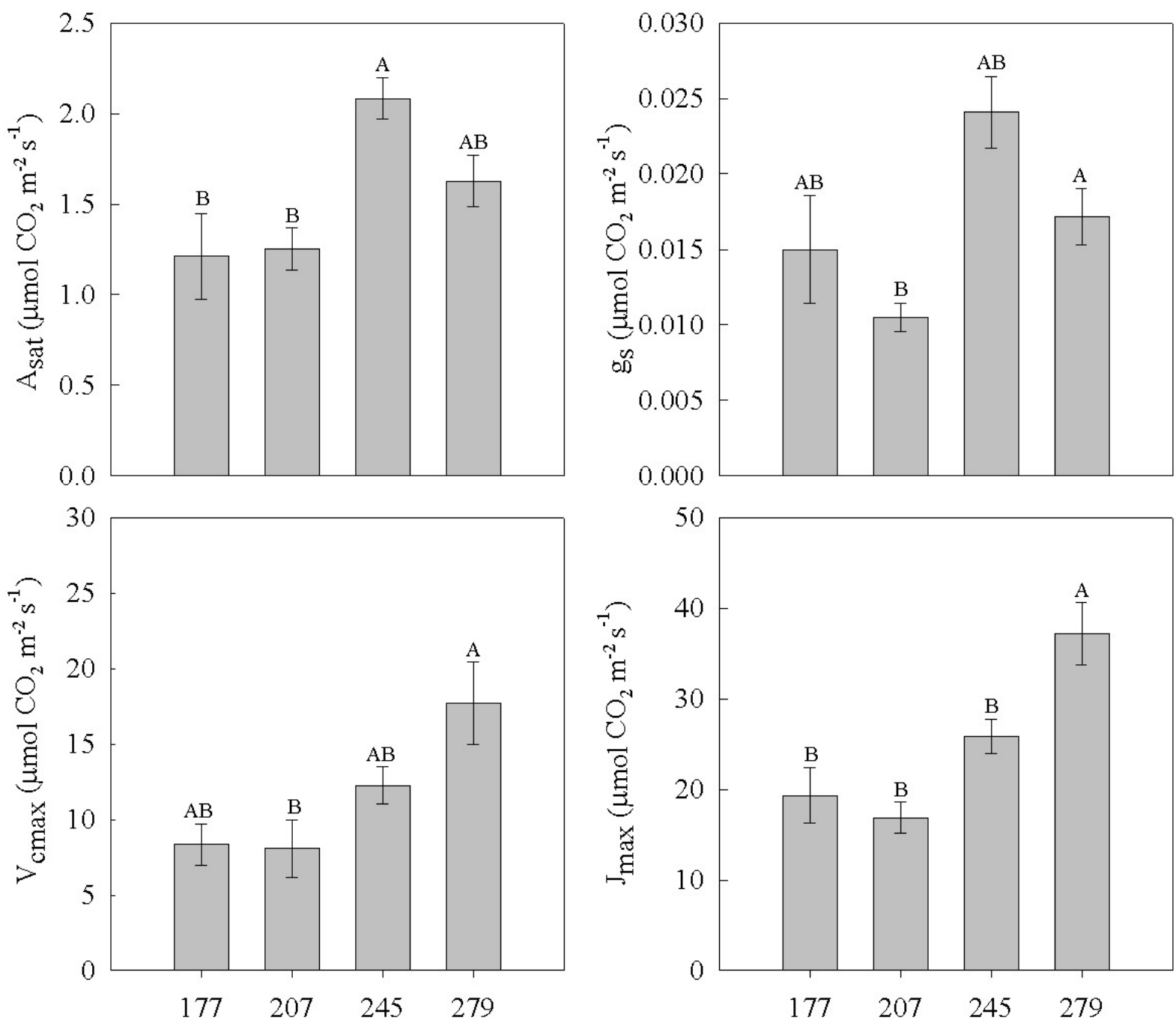

Julian day, 2008

Figure 3. Steady state light-saturated photosynthesis (A), stomatal conductance (B) and modeled (from A-C $C_{i}$ curves) carboxylation (C) and electron transport (D) measured across the 2008 growing season (means \pm 1 $\mathrm{SE}$ ). All measurements were made in saturating light of $1500 \mu \mathrm{mol} \mathrm{m}^{-2} \mathrm{~s}^{-1}$ and $380 \mu \mathrm{CO}_{2} \mathrm{l}^{-1}$ air with $\mathrm{n}=3$ for day 177 and $n=11$ for subsequent days. Bars separated by different letters are significantly different. 

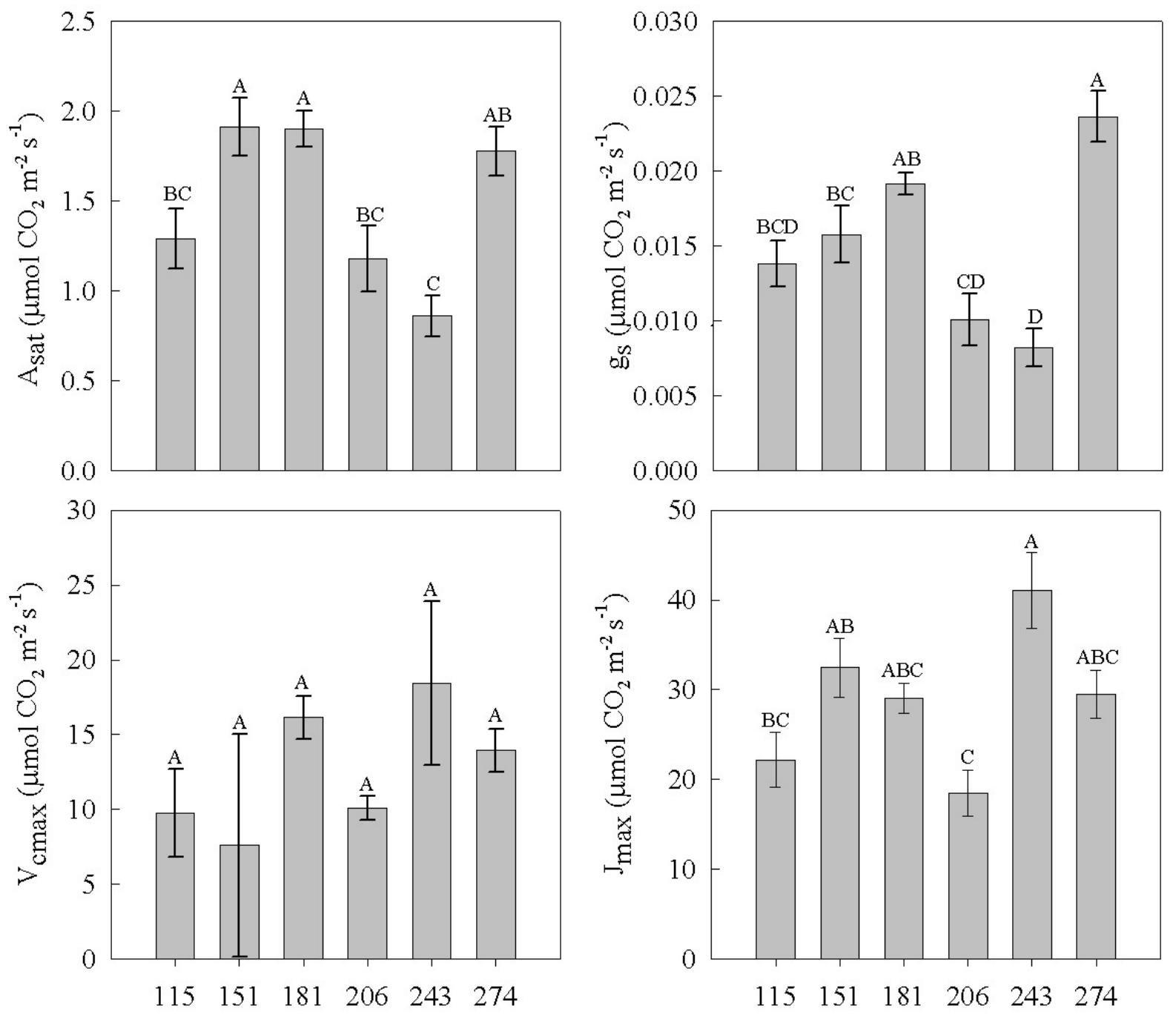

Julian day, 2009

Figure 4. Steady state light-saturated photosynthesis (A), stomatal conductance (B) and modeled (from A-C $i$ curves) carboxylation (C) and electron transport (D) measured across the 2009 growing season (means \pm 1 $\mathrm{SE}$ ). All measurements were made in saturating light of $1500 \mu \mathrm{mol} \mathrm{m}^{-2} \mathrm{~s}^{-1}$ and $380 \mu \mathrm{CO}_{2} \mathrm{l}^{-1}$ air with $\mathrm{n}=10$ for all sampling dates. Bars separated by different letters are significantly different. 


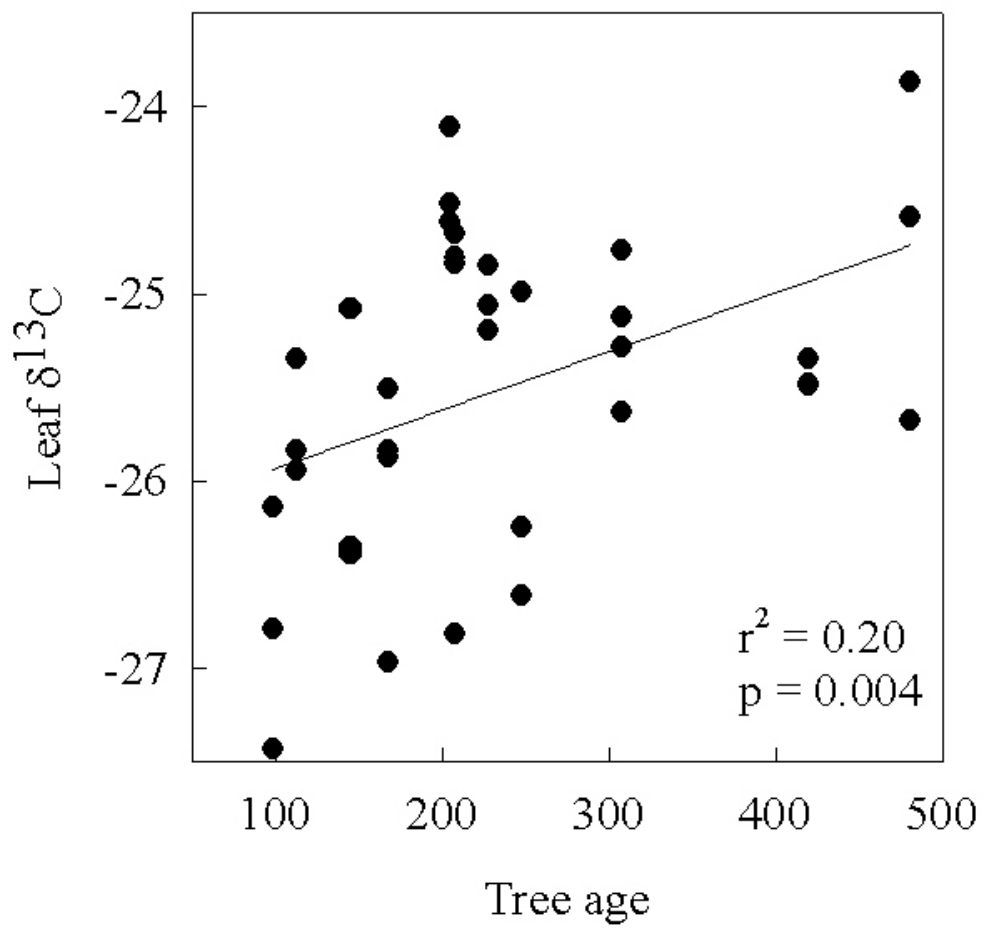

Figure 5. Leaf isotopic composition $\left(\delta^{13} \mathrm{C}\right)$ of Juniperus virginiana needles. Needles that were sampled were assumed to be current year tissue. 


\title{
CHAPTER 3: Investigation of Juniperus virginiana growth during the past century using $\delta^{13} \mathrm{C}$
}

\begin{abstract}
This study examined the relationships between tree growth during the past century, climate, the ratio of internal carbon dioxide concentration to atmospheric $\mathrm{CO}_{2}$ concentration $\left(C_{i} / C_{a}\right)$ and intrinsic water-use efficiency ( $i$ WUE) by analyzing $\delta^{13} \mathrm{C}$ in tree rings of Juniperus virginiana growing on a limestone outcrop in West Virginia, US. Tree rings from years 1909 to 2008 from five Juniperus virginiana trees that ranged from 98 years to 480 years in age were measured for basal area growth and used for isotopic analysis. Intrinsic WUE increased from approximately 47 to $77 \mu \mathrm{mol} \mathrm{mmol}^{-1}$ over the past century, representing a $64 \%$ increase. In addition, we found a positive relationship between $i$ WUE and the basal area increase over this time period, suggesting the increase in WUE translated into greater growth of the Juniperus trees. Typically, it might be expected that increased growth of these trees reflects increased photosynthesis and decreased stomatal conductance resulting from increased atmospheric $\mathrm{CO}_{2}$ concentrations. However, this area of the central Appalachian Mountains has historically received some of the highest rates of acid deposition in the nation resulting from being downwind from an abundance of coal-fired power plants in the Ohio River valley. Our results show that $C_{i} / C_{a}$ declined $12 \%$ between 1909 and 1980, but increased $8.6 \%$ between 1980 and 2008 . We hypothesize that the directional change in $C_{i} / C_{a}$ that occurred around 1980 was due to a reduction in sulfur emissions imposed by the Clean Air Act, environmental legislation enacted in 1970 and amended in 1990. Sulfur deposition measured by the National Atmospheric Deposition Program (NADP) in West Virginia near our Juniperus site shows a 53\% decline between 1979 and 2009 and these NADP data show a highly significant negative correlation with $C_{i} / C_{a}$ of Juniperus over this time period. Previously, experimental studies have shown that acidic sulfur mist leaches calcium from leaves causing a reduction in stomatal control and lowering internal leaf $\mathrm{CO}_{2}$ concentrations. Thus, these tree-ring data show proxy evidence for physiological responses to increased $\mathrm{CO}_{2}$ over the previous century, but also provide a biotic signature illustrating the role of environmental legislation to alleviate environmental pollution at large spatial and temporal scales.
\end{abstract}

\section{Introduction}

Trees contain an annually defined record of physiological response to the environment in annual growth rings that may provide a proxy of past climate (Fritts 1976; Cook and Kairiukstis 1990). Traditionally, the response to the environment has been examined using ring width measurements, but stable isotopic content of the wood in tree rings also provides a record of physiological response to the environment that may be independent of the local climate record (McCarroll and Loader 2004). By incorporating the stable isotopic signature record with traditional tree-rings analyses, we may be able to extend local climate histories and establish relationships investigating multiple environmental factors that affect the physiological processes of trees over time. 
The isotopic signature of carbon from wood in tree-rings reflects known environmental effects on foliar gas exchange (Dawson and Ehleringer 1993) linked through the ratio of the $\mathrm{CO}_{2}$ concentration inside the leaf $\left(C_{i}\right)$ to the atmospheric $\mathrm{CO}_{2}$ concentration $\left(C_{a}\right)$ (Farquhar et al. 1989). In addition, tree rings have recorded the decrease in the ratio of ${ }^{13} \mathrm{C} /{ }^{12} \mathrm{C}$ caused by anthropogenic inputs of $\mathrm{CO}_{2}$ into the atmosphere (the Seuss effect; Feng 1999). However, this decrease in the isotopic signature due to anthropogenic increases in atmospheric $\mathrm{CO}_{2}$ concentration is not completely understood. Two possible explanations have been suggested for the way plants may respond to these changes. There may be a passive response where the tree does not respond to changes in $C_{a}$ and thus, $C_{a}$ minus $C_{i}$ remains constant or there may be an active response by which the tree maintains a constant $C_{i} / C_{a}$ ratio through stomatal regulation (McCarroll et al. 2009). Experimental investigation of this phenomenon has reported both responses pointing to a nonlinear and heterogeneous relationship between $C_{a}$ and $C_{i}$ (Waterhouse et al. 2004; Loader et al. 2008; Duquesnay et al. 1998) and indicating the need for careful analysis and interpretation of experimental data. Plant water use efficiency (WUE), carbon gain per unit water loss, provides a measurement by which we can track how trees may be changing their physiological functioning as atmospheric $\mathrm{CO}_{2}$ increases. As more $\mathrm{CO}_{2}$ is available to the tree an increase in WUE is possible due to the higher concentration gradient of $\mathrm{CO}_{2}$ into the leaf causing partial stomatal closure, and thereby maintaining carbon supply for photosynthesis while limiting water loss through transpiration. Once a greater understanding of physiological response to environment is established these tree ring width and isotopic chronologies can be used in an attempt to create a more robust historical context of climate patterns.

By combining isotopic and traditional dendrochronological tree-ring proxies that are influenced by similar primary pathways (e.g., air temperature) and different secondary pathways (e.g., source of precipitation), a stronger biological/climate correlation may be generated (Gagen et al. 2006). Once isotopic tree-ring chronologies are better understood through the analysis of physiological responses to changes atmospheric composition (Loader et al. 2008; Treydte et al. 2007) tree-ring isotope analyses may be used to strengthen dendrochronological studies investigating climatic variability. This may allow for the identification of years with growing seasons that were both dry and warm or cool and wet (Gagen et al. 2004; McCarroll et al. 2003). Predictions of future climate are constrained by our ability to analyze and interpret historical climate patterns. While tree-ring records offer annually defined indices of local environmental history, the spatial distribution of usable tree-ring chronologies is limited to regions affected by highly variable climatic conditions. In eastern North America, dendrochronological climate studies have had limited success because the temperate climate often lacks high frequency fluctuations, constraining the climate - tree ring record, resulting in the exclusion of this region from many studies (Treydte et al. 2007). Careful selection of tree species and site can strengthen climate signals, although this does not guarantee isolation of reliable dendrochronological climate proxy (McCarroll and Loader 2004). Isolating climate signals from noise present due to stand age and dynamics is often difficult. Signals in temperate regions can be affected by changes in nutrient availability (Sheppard et al. 2001), physical damage (Smolnik et al. 2006) and stand dynamics (Cook 1987). For these reasons, tree ring records in temperate regions often fail to provide good 
proxies of climate, such as mean air temperatures. Since tree rings integrate growing season environmental conditions into a single record, environmental conditions experienced by the tree during the non-growing season (e.g., winter temperature extremes) are often not recorded in tree-rings (Jones et al. 2003). Developing methods to utilize the information recorded in the tree-rings of temperate regions would be an invaluable record of local climate variability. This study developed a chronology of both ring-width and $\delta^{13} C$ for a stand of Juniperus virginiana (Eastern red cedar) in a temperate region of eastern North America using traditional dendrochronological and isotopic techniques. The red cedar chronology was first used to determine whether anthropogenic inputs of $\mathrm{CO}_{2}$ impacted the $\delta^{l 3} \mathrm{C}$ signatures recorded in tree-rings. The chronology of isotopically derived $C_{i} / C_{a}$ ratios and WUE was used to examine how these diagnostics of photosynthetic capacity changed over time, as well as possible environmental and anthropogenic influences. Finally, the data was used to determine whether these J. virginiana trees contained a signal linking physiological response to local weather patterns, as well as large-scale climatic or meteorological shifts (Stenseth et al. 2003). In comparing global climate patterns with singular local climate signals, the data was used to isolate which atmospheric patterns most influenced yearly growth of this stand of trees.

\section{Methods}

\section{Study site and experimental approach}

Our study site was a stand of Juniperus virginiana (red cedar) trees that is located along the South branch of the Potomac River in southern Grant County, West Virginia, USA (38 53'1.95"N 79 $14^{\prime} 10.05^{\prime \prime}$ ) and is characterized as a cedar or limestone glade (Bartgis 1993). The site is approximately 0.1 hectares, 670 meters above sea level, with full northwestern exposure to extreme weather events. The shallow soil is primarily composed of broken limestone and little organic matter. In addition to red cedar, the open overstory vegetation is comprised of Quercus muhlenbergii, Quercus alba, Fraxinus americana, and Juglans nigra. Precipitation and temperature data used in this study were combined from three sources to develop a complete 100-year record: Petersburg, WV, WV region 6 weather data (West Virginia Climate Region Six Data. NOAA/NCDC), and Parameter-elevation Regressions on Independent Slopes Model data (PRISM Climate Group, Oregon State University, http://www.prismclimate.org, created 10 October 2009; Kalnay et al. 1996). Nitrogen and sulfur deposition used in this study was collected by the National Atmospheric Deposition

Program (NADP) at the NADP Monitoring Location WV18 in Parsons, WV (http://nadp.sws.uiuc.edu/sites/siteinfo.asp?net=NTN\&id=WV18).

Five red cedar trees were randomly selected along a transect running parallel to the bluff $6 \mathrm{~m}$ from the edge. Trees were cored using a $5 \mathrm{~mm}$ diameter increment borer and prepared using standard dendrochronology techniques (Stokes and Smiley 1968). Cores were cross-dated using WinDENDRO (Regent Instruments Inc. Quebec City, Canada 2009) with a master chronology created previously for the site using $<20$ red cedar trees and all chronologies correlated with the master chronology with an expressed population signal (EPS) $\leq 65 \%$ (Maxwell et al. 2011). Ring widths were standardized using ARSTAN (Cook 1986) with a 100-year smoothing spline to remove juvenile effects. The residual index of tree-ring width was used for subsequent analyses. The five trees were aged to be between 98 and 480 years old. Ring width 
measurements from the year 1909 to 2007 were used to calculate basal area increment (BAI) as a measure of total tree growth for the given year using,

$$
B A I=\pi\left(R_{n}^{2}-R_{n-1}^{2}\right),
$$

where $\mathrm{R}$ is tree radius and $\mathrm{n}$ is the year of ring formation (Silva et al. 2010).

Tree rings for years 1909 to 2008 were collected for isotopic analysis by scalpel dissection of cores under $5 \mathrm{x}$ magnifications at the boundary of late wood and early wood. Wood samples were re-cut to $1 \mathrm{mg}$ and packed into tin capsules for carbon isotopic analysis. Within years, early and latewood were combined for sample analysis to ensure enough material for peak detection in the isotopic analysis. Samples were analyzed for $\delta^{13} \mathrm{C}$ with a ThermoFinnigan Conflow III interface and Finnigan Delta-plus Continuous Flow Stable Isotope Ratio Mass Spectrometer (IRMS, Waltham, Massachusetts). PeeDee River belemnite (PDB) was used as the standard to which the samples were compared. Samples had a with-in run variation of $0.07 \%$ o and laboratory standards had a variation of $<0.04 \%$. Whole wood samples were corrected by $-3.2 \%$ o to account for the differences between leaf and wood isotopic signature. This value was calculated from the difference between current year leaf isotopic values and those of the outer most ring of radial growth (Other estimates of the offset between wood tissue and leaf tissue have been similar, e.g. Juniperus californica, Ward et al. 2005).

\section{$\Delta^{13} C$ and calculation of $C_{i} / C_{a}$ and intrinsic water use efficiency}

Carbon isotope discrimination $\left(\Delta^{13} \mathrm{C}\right)$ was calculated according to (Farquhar et al. 1982) using,

$$
\Delta^{13}=\left(\frac{\delta^{13} C_{\text {air }}-\delta^{13} C_{\text {plant }}}{\frac{1+\delta^{13} C_{\text {plant }}}{1000}}\right)
$$

where $\delta^{13} \mathrm{C}_{\text {plant }}$ were $\delta^{13} \mathrm{C}_{\text {wood }}$ values corrected with the $-3.2 \%$ o wood to leaf offset and $\delta^{13} \mathrm{C}_{\text {air }}$ values were atmospheric values for the specific year of the tree ring from direct atmospheric measurements (Scripps $\mathrm{CO}_{2}$ program, Scripps Institution of Oceanography; Keeling et al. 2010) and the Law Dome ice cores (Etheridge et al. 1998). The $\mathrm{C}_{i} / \mathrm{C}_{a}$ ratio was calculated from $\Delta^{13} C$ according to Farquhar et al. (1982) using the following equations;

$$
\begin{aligned}
& \Delta^{13} C=a+(b-a){ }^{C} / C_{a}, \\
& C_{i} / C_{a}=\frac{\Delta-a}{b-a}, \\
& C_{i}=C_{a}\left(C_{i} / C_{a}\right),
\end{aligned}
$$

where $a$ is the fractionation constant due to diffusion of $\mathrm{CO}_{2}$ through the stomatal aperture (4.4\%, O'Leary $1981)$ and $b$ is the fractionation constant due to ribulose-1,5-bisphosphate carboxylase-oxygenase (27\%o, Farquhar and Richards 1984). Values of $C_{a}$ and $C_{i}$ were used to determine intrinsic water use efficiency (iWUE) (McCarroll and Loader 2004) where, 


$$
i \mathrm{WUE}=\mathrm{A} / \mathrm{g}_{\mathrm{s}}=\left(C_{i}-C_{a}\right) 0.625,(7)
$$

Atmospheric $\mathrm{CO}_{2}$ concentrations for the specific year of the tree ring were taken from direct atmospheric measurements (Scripps $\mathrm{CO}_{2}$ program, Scripps Institution of Oceanography; Keeling et al. 2010) and the Law Dome ice cores (Etheridge et al. 1998).

\section{Correlations between ring widths and $\delta^{13} \mathrm{C}$ with climatic variables}

Relationships between ring widths, carbon isotopic values and climate variables were investigated using regression analysis. Local climate signals investigated included mean monthly precipitation, mean monthly temperatures, minimum temperatures, maximum temperatures, total yearly precipitation, monthly precipitation and Palmer Drought Severity Index (PDSI).

\section{Statistical analyses}

Average annual BAI, $\delta^{l 3} C, C_{i} / C_{a}$, and $i \mathrm{WUE}$ from 1909 to 2008 for $J$. virginiana at the cedar glade site were calculated. Regression analyses were used to determine the lines of best fit in the temporal trends of BAI, $\delta^{13} C, C_{i} / C_{a}$, and $i \mathrm{WUE}$ of trees in each study over the 100-year period using correlation analysis and best-fit line functions in Excel (Microsoft Corporation, Redmond, WA).

In order to examine the correlations between ring widths and $\delta^{13} C$ of $J$. virginiana with climatic variables, values of $\delta^{13} C$ were standardized into an index value using a standard score (z-score). These index values along with tree ring indices were compared against climate indices with simple linear correlations using the correlation analysis tool in Excel (Microsoft Corporation, Redmond, WA). Statistical significance of these relationships were assessed using JMP ver. 10 (SAS, Cary, NC) or Sigmaplot 10 (Systat Software Inc., Evanston, IL).

\section{Results}

Temporal trends in $\delta^{13} C, C_{i} / C_{a}$, iWUE and BAI of J. virginiana trees

Carbon isotope abundance of $J$. virginiana tree rings followed a nonlinear temporal trend between the years 1910 to 2008, reflecting the changing source of atmospheric $\mathrm{CO}_{2}$ due to fossil fuel emissions as well as the physiology of the trees (Figure 1). The $\Delta^{13} \mathrm{C}$ indicates how the plant changed the way it discriminated against the heavier isotope over time, changing over time (Figure 2). Likewise, $C_{i} / C_{a}$, calculated from $\Delta^{13} \mathrm{C}$ followed a nonlinear temporal trend (Figure 3). The $C_{i} / C_{a}$ ratio of $J$. virginiana declined $12.2 \%$ from 1909 and 1982, but then increased 8.6\% from 1982 to 2008 (Figure 3). Intrinsic WUE increased linearly over the past century $(\mathrm{y}=0.309 \mathrm{x}-543.2$;

$\left.\mathrm{r}^{2}=0.89\right)$ representing a $64 \%$ increase in $i$ WUE over the last century from approximately 47 to $77 \mu \mathrm{mol} \mathrm{CO}_{2} \mathrm{mmol}^{-1} \mathrm{H}_{2} \mathrm{O}$ (Figure 5). 
Tree growth inferred from the BAI of the $J$. virginiana tree rings showed an exponential increase between 1909 and $2008\left(\mathrm{y}=\left(7 \times 10^{-19}\right)^{0.0219 x} ; r^{2}=0.81 ; \mathrm{p}<\right.$; Figure 6). Because of the linear increase in $i$ WUE over time, there was an exponential relationship between BAI and $i$ WUE $\left(\mathrm{y}=0.011901^{0.057 x} ; \mathrm{r}^{2}=0.80\right.$; $\mathrm{p}<0.0001$; Figure 7).

There was a negative relationship between $C_{i} / C_{a}$ calculated from wood carbon isotope abundance of J. virginiana and anthropogenic deposition rates of $\mathrm{SO}_{4}\left(\mathrm{y}=0.00005 \mathrm{x}^{2}-0.004 \mathrm{x}+0.5835 ; \mathrm{r}^{2}=0.31, \mathrm{p}<0.0073\right)$ and $\mathrm{NO}_{3}\left(\mathrm{y}=0.0003 \mathrm{x}^{2}-0.156 \mathrm{x}+0.67 ; \mathrm{r}^{2}=0.43, \mathrm{p}<0.0073\right.$; Figure 8$)$.

\section{Discussion}

Stable carbon isotope abundance in tree rings provides an indication of physiological functioning over time and may also provide indices of past climate variability which can be used to strengthen dendrochronological climate reconstructions (Spiker and Hatcher 1987, Schleser et al. 1999). In this study using old J. virginiana trees growing on a cedar glade rock outcrop in West Virginia, wood $\delta^{13} \mathrm{C}$ provided many insights into tree response to past climate variability. However, $\delta^{13} \mathrm{C}$ and tree ring indices did not contain a corresponding record of past climate and neither index provided an overly strong correlation with weather patterns of this temperate area of the eastern U.S. Instead, wood $\delta^{13} \mathrm{C}$ provided strong proxy evidence for physiological responses to increased $\mathrm{CO}_{2}$ over the previous century and may also provide a biotic signature illustrating the role of environmental legislation to alleviate environmental pollution at large spatial and temporal scales. This suggests that plant response to anthropogenic environmental change needs to be considered in interpreting climate signals using either stable isotopes or traditional dendrochronology.

In this study, $i$ WUE, or the ratio of photosynthesis to stomatal conductance to water, of J. virginiana increased linearly by $44 \%$ over last century (Figure 3). Many isotopic studies using tree rings of species in the Northern hemisphere have found the similar results (Arneth et al. 2002; Bert et al. 1997; Feng 1999; Sauer et al. 2004; Waterhouse et al. 2004; Liu et al. 2007; Sauer et al. 2008; Silva et al. 2010). Atmospheric $\mathrm{CO}_{2}$ has been increasing since the beginning of the industrial revolution and has increased by about $30 \%$ since the early $20^{\text {th }}$ century (IPCC 2008). Plants may respond to increasing $\mathrm{CO}_{2}$ by increasing their photosynthetic rates and by partially closing their stomatal pores and WUE of the plant is increased by these responses either in combination or separately (Morison 1993; Overdieck \& Forstreuter 1994; Picon et al. 1996; Morgan et al. 2004.). A recent meta-analysis of 47 tree-ring studies from several different forest types found that $i$ WUE of trees has increased by about $20 \%$ over the last 40 years (Peñuelas et al. 2011).

A surprising result in this study is that BAI, a proxy for tree growth, of J. virginiana increased exponentially over the last part of the $20^{\text {th }}$ century despite that the age of the trees used in this study ranged from 98 to 480 years old (Figure 4), typically much older than expected for exponential growth. A similar growth trend for old $J$. virginiana trees has been observed in a study with a much greater sample size at this stand in WV and two other nearby J. virginiana stands (Maxwell et al. 2011). The strong correlation between $\mathrm{BAI}$ and $i \mathrm{WUE}$ of $J$. virginiana (Figure 5) suggests that the increased $i$ WUE over the last century has greatly contributed to the increased growth of these trees. On the other hand, in the meta-analysis by Peñuelas $e t a l$. 
(2011), about half of the studies showed reduced growth by trees despite having increased $i$ WUE during the past 40 years. Silva et al. (2010) concluded that tree growth of four tree species along a latitudinal gradient from boreal forest to southern deciduous forest showed a decline in growth during the later part of the $20^{\text {th }}$ century due to a changing climate, despite having a 53\% increase in $i$ WUE over the last century.

It cannot be concluded that the increased BAI of J. virginiana that occurred during the later part of the $20^{\text {th }}$ century was due to increased atmospheric $\mathrm{CO}_{2}$. In fact, there are several factors that more than likely have been acting on these plants synergistically to cause the increase in tree growth and $i$ WUE, with one factor possibly being increased $\mathrm{CO}_{2}$. Another factor may be that spring precipitation increased in this area of WV during the later part of $20^{\text {th }}$ century (Maxwell et al. 2011), a factor that could be very important for growth of trees on a rock outcrop with very thin soil. However, this effect could not be detected using the proxy evidence provide by wood $\delta^{13} \mathrm{C}$ of $J$. virginiana for physiological responses that should be sensitive to greater water availability.

The most important factor affecting BAI of J. virginiana at this site in the latter half of the $20^{\text {th }}$ century and one that would act synergistically with elevated $\mathrm{CO}_{2}$ and precipitation may be the reduction in emissions of $\mathrm{SO}_{4}$ and $\mathrm{NO}_{3}$ electric power generation plants after the enactment of the Federal Clean Air Act of 1970 and subsequent amendments. The surrounding area of WV that contains this study site has historically had some of the highest rates of acid deposition, including both $\mathrm{SO}_{4}$ and $\mathrm{NO}_{3}$, in the U.S. However, there has been a $60 \%$ reduction in $\mathrm{SO}_{4}$ deposition and a $45 \%$ reduction in $\mathrm{NO}_{3}$ deposition in this area of the U.S. since 1978 (Figure 6 upper; http://nadp.sws.uiuc.edu/sites/siteinfo.asp?net=NTN\&id=WV18). Numerous studies have shown that acid deposition disrupts cation cycling in forest ecosystems and limits the availability of soil $\mathrm{Ca}^{2+}$ and $\mathrm{Mg}^{2+}$ for tree uptake and use for growth (Likens et al. 1996; Driscoll et al. 2001). In addition, canopies of forests that receive high amounts of acid rain experience significant leaching of calcium from leaves (Joslin et al. 1988). Field studies have shown that acid rain can cause the loss of over 1/3 of foliar Ca of red spruce needles (Joslin et al. 1988). Experimental misting of foliage with acidic N and S implicated that S deposition, and not $\mathrm{N}$ deposition, was responsible for Ca leaching (Eamus 1993) and that the lost Ca was from the labile pool of $\mathrm{Ca}$ in cells that is associated with membranes (Schaberg et al. 2000). Further, the loss of foliar $\mathrm{Ca}$ due to acidic misting has been show to result in membrane destabilization and loss of cold tolerance (DeHayes et al. 1999; Schaberg et al. 2000), reduced photosynthesis and increased dark respiration (McLaughlin et al. 1991; McLaughlin and Tjoelker 1992; McLaughlin et al. 1993; Eamus 1993; Ellsworth and Liu 1994), and impaired stomatal function including, lower stomatal conductance (Eamus 1993), a smaller maximum stomatal aperture (Borer et al. 2005), the loss of stomatal sensitivity to light (Eamus 1993), and the loss of stomatal sensitivity to water stress (Borer et al. 2005). Foliage damage, loss of foliage, and reduced radial growth of have also been observed in red spruce trees subjected to acid rain (Johnson et al. 1988, LeBlanc and Raynal 1990). In this study, $\delta^{13} \mathrm{C}$ from the chronosequence of $J$. virginiana tree rings show that the $\mathrm{C}_{\mathrm{i}} / \mathrm{C}_{\mathrm{a}}$ ratio decreased by $12.2 \%$ from 1909 to 1982 , after which $\mathrm{C}_{\mathrm{i}} / \mathrm{C}_{\mathrm{a}}$ increased by $8.6 \%$ through 2009 (Figure 2). The reduction in $\mathrm{C}_{\mathrm{i}} / \mathrm{C}_{\mathrm{a}}$ from 1909 to 1982 might be explained by atmospheric $\mathrm{CO}_{2}$ enrichment, where increasing $\mathrm{CO}_{2}$ over this time period reduces stomatal conductance of J. virginiana trees, 
or it could be explained by the effect of $\mathrm{SO}_{4}$ deposition on stomatal function of the J. virginiana trees. Increasing $\mathrm{CO}_{2}$, however, cannot explain the increase in $\mathrm{C}_{\mathrm{i}} / \mathrm{C}_{\mathrm{a}}$ that occurs from 1982 to 2009 , where $\mathrm{C}_{\mathrm{i}} / \mathrm{C}_{\mathrm{a}}$ returns to early 1900 levels. On the other hand, the return of stomatal function of J. virginiana as $\mathrm{SO}_{4}$ deposition declines can explain the observed increase in $\mathrm{C}_{\mathrm{i}} / \mathrm{C}_{\mathrm{a}}$. While we do not have records of sulfur and nitrogen deposition in this area of WV before 1978, those measured since 1978 indicate a significant correlation between increased $\mathrm{C}_{\mathrm{i}} / \mathrm{C}_{\mathrm{a}}$ of J. virginiana with reductions in $\mathrm{SO}_{4}$ deposition $\left(\mathrm{y}=0.00005 \mathrm{x}^{2}-0.004 \mathrm{x}\right.$ $\left.+0.5835 ; \mathrm{r}^{2}=0.31, \mathrm{p}<0.0073\right)$ and $\mathrm{NO}_{3}\left(\mathrm{y}=0.0003 \mathrm{x}^{2}-0.156 \mathrm{x}+0.67 ; \mathrm{r}^{2}=0.43, \mathrm{p}<0.0073 ;\right.$ Figure 6).

Ring proxy data

Creating strong indexes of climate based on tree rings relies on the assumption that trees maintain consistent environmental responses over the time courses of centuries to millennia. The trend towards enriched ring $\delta^{13} \mathrm{C}$ may indicate that these trees are regulating stomata in response to increased availability of $\mathrm{CO}_{2}$. The reduced stomatal conductance is responsible for less discrimination of the heavier isotope. Regulation of stomata may be shifting again as the concentration of $\mathrm{CO}_{2}$ continues to increase (Figure 3 Francey and Farquhar 1982; Ehleringer and Cerling 1995). Additionally these weak relationships may be due changes in atmospheric deposition of nitrogen (McLauchlan et al. 2007). The strong relationship present between $\mathrm{C}_{i} / \mathrm{C}_{a}$ and deposition of both nitrogen and sulfur illustrates the importance of investigating alternative explanations to changes seen in forest productivity. As such, it points to the importance of an interdisciplinary approach when investigating tree ring data sets.

\section{Conclusions}

The link between $\mathrm{C}_{i} / \mathrm{C}_{a}$ and deposition of both nitrogen and sulfur is evidence that regulations put in place by congress have had noticeable effects on tree physiology. In an area of tree physiology that has focused primarily on the effect of rising $\mathrm{CO}_{2}$ concentrations this link may lead to investigating other possible drivers of physiological change in trees. The weak link between ring proxy data and climate may be further explained by discovery of other stronger drivers of physiology such as pollution. The strong positive influence of increased carbon dioxide concentration on productivity also contributed to the weak correlations with climate. Further analysis of this site with a more robust set of ring proxy data may be able to better assess links with tree productivity and climate. Including an analysis of larger climatic patterns such as the arctic oscillation and El Nino Southern Oscilation with local climate may provide insight into the long term climate patterns of the region. 


\section{Literature Cited}

Arneth A, Lloyd J, Šantruková H, Bird M, Grigoriev S, Gleixner G, Schulze ED (2002) Response of central Siberian Scots pine in to soil water deficit and long-term trends in atmospheric $\mathrm{CO}_{2}$ concentration, Global Biogeochemical Cycles 16(1): 5/1-5/13.

Bert D, Leavitt SW, Dupouey JL (1997) Variations of wood $\delta^{13} \mathrm{C}$ and water-use efficiency of Abies alba during the last century. Ecology 78: 1588-1596.

Bartgis RL (1993) The limestone glades and barrens of West Virginia. Castanea 58: 69-89.

Borer CH, Schaberg PG, Dehayes DH (2005) Acidic mist reduces foliar membrane-associated calcium and impairs stomatal responsiveness in red spruce. Tree Physiology 25: 673-680.

Cook ER, Holmes RL (1986). Users manual for program Arstan. Holmes RL, Adams RK, Fritts HC (eds.). Tree-ring chronologies of western North America: California, eastern Oregon and northern Great Basin. Chronology Series 6, Laboratory of Tree-Ring Research, Univ. of Arizona, Tucson, 50-65.

Cook ER, Johnson AH, Blasing TJ (1987) Forest decline: modeling the effect of climate in tree rings. Tree Physiology 3:27-40.

Cook ER, Kairiukstis LA, eds. (1990) Methods of Dendrochronology. Kluwer Academic Publishers, Dordrecht, Netherlands.

Dawson TE, Ehleringer JR (1993) Isotopic enrichment of water in the woody tissue of plants: implications for plant water source, water uptake, and other studies which use stable isotopes. Geochimica et Cosmochimica Acta 57:3487-3492.

DeHayes DH, Schaberg PG, Hawley GJ, Strimbeck GR (1999) Acid rain impacts calcium nutrition and forest health. Bioscience 49: 789-800.

Driscoll CT, Lawrence GB, Bulger AJ, Butler TJ, Cronan CS, Eagar C, Lambert KF, Likens GE, Stoddard JL, Weathers KC. (2001) Acidic deposition in the northeastern United States: Sources and inputs, ecosystem effects, and management strategies. Bioscience 51(3): 180-198.

Duquesnay A, Bréda N, Stievenard M, Dupouey DL (1998) Changes of tree-ring $\delta^{13} \mathrm{C}$ and water-use efficiency of beech (Fagus sylvatica L.) in north-eastern France during the past century. Plant, Cell and Environment 6: 1365-3040.

Eamus D (1993) Assimilation and stomatal conductance responses of red spruce to midwinter frosts and the constituent ions of acid mist. Tree Physiology 13(2): 145-155.

Ehleringer JR, Cerling TE (1995) Atmospheric $\mathrm{CO}_{2}$ And The Ratio Of Intercellular To Ambient $\mathrm{CO}_{2}$ Concentrations In Plants. Tree Physiology 15:105-111.

Ellsworth DS, Liu X (1994) Photosynthesis and canopy nutrition of four sugar maple forests on acid soils in northern Vermont. Canadian Journal of Forest Research 24: 2118-2127. 
Etheridge DM, Steele LP, Langenfelds RL, Francey RJ, Barnola JM, Morgan VI (1998) Historical $\mathrm{CO}_{2}$ records from the Law Dome DE08, DE08-2, and DSS ice cores. In Trends: A Compendium of Data on Global Change. Carbon Dioxide Information Analysis Center, Oak Ridge National Laboratory, U.S. Department of Energy, Oak Ridge, Tenn., U.S.A.

Farquhar GD, O'Leary MH, Berry JA (1982) On the relationship between carbon isotope discrimination and intercellular carbon dioxide concentration in leaves. Aust. J. Plant Physiol. 9: 121-137.

Farquhar GD, Ehleringer JR, Hubick KT (1989) Carbon Isotope Discrimination And Photosynthesis. Annual Review of Plant Physiology and Plant Molecular Biology 40:503-537.

Feng XH (1999) Trends in intrinsic water-use efficiency of natural trees for the past 100-200 years: A response to atmospheric CO2 concentration. Geochimica Et Cosmochimica Acta 63:1891-1903.

Francey RJ, Farquhar GD (1982) An explanation of the 13C/12C variations in tree rings. Nature 297: 2831.

Fritts HC (1976) Tree rings and climate. London, New York and San Francisco: Academic Press.

Gagen M, McCarroll D, Edouard JL (2004) Latewood width, maximum density, and stable carbon isotope ratios of pine as climate indicators in a dry subalpine environment, French Alps. Arctic Antarctic and Alpine Research 36:166-171.

Gagen M, McCarroll D, Edouard JL (2006) Combining ring width, density and stable carbon isotope proxies to enhance the climate signal in tree-rings: An example from the southern French Alps. Climatic Change 78:363-379.

Johnson AH, Cook ER, Siccama TG (1988) Climate and red spruce growth and decline in the northern Appalachians. Proceedings of the National Academy of Sciences 95:5369-5373.

Jones PD, Briffa KR, Osborn TJ (2003) Changes in the Northern Hemisphere annual cycle: Implications for paleoclimatology? Journal of Geophysical Research-Atmospheres 108: 4588-4595.

Joslin JD, McDuffie C, Brewer PF (1988) Acidic cloud water and cation loss from red spruce foliage. Water, Air and Soil Pollution 39: 355-363.

Kalnay E, Kanamitsu M, Kistler R, Collins W, Deaven D, Gandin L, Iredell M, Saha S, White G, Woollen J, Zhu Y, Chelliah M, Ebisuzaki W, Higgins W, Janowiak J, Mo KC, Ropelewski C, Wang J, Leetmaa A, Reynolds R, Jenne R, Joseph D (1996). The NCEP/NCAR 40-Year Reanalysis Project. Bulletin of the American Meteorological Society 77: 437-471.

Keeling RF, Piper SC, Bollenbacher AF, Walker SJ (2010) Monthly atmospheric ${ }^{13} \mathrm{C}^{12} \mathrm{C}$ isotopic ratios for 11 SIO stations. A Compendium of Data on Global Change. Carbon Dioxide Information Analysis Center, Oak Ridge National Laboratory, U.S. Department of Energy, Oak Ridge, Tenn., U.S.A.

LeBlanc DC and Raynal DJ (1990) Red spruce decline on Whiteface Mountain, New York: II. Relationships between apical and radial growth decline. Canadian Journal of Forest Research 20:1415-1421. 
Likens GE, Driscoll CT, Buso DC (1996) Long-term effects of acid rain: Response and recovery of a forest ecosystem. Science 272: 244-246.

Liu XH, Shao XM, Wang LL, Zhao LJ, Wu P, Chen T, Qin DH, Ren JW (2007) Climatic significance of the stable carbon isotope composition of tree-ring cellulose, comparison of Chinese hemlock (Tsuga chinensis Pritz) and alpine pine (Pinus densata Mast) in a temperate-moist region of China. Science in China, Series D: Earth Sciences 50:1076-1085.

Loader NJ, Santillo PM, Woodman-Ralph JP, Rolfe JE, Hall MA, Gagen M, Robertson I, Wilson R, Froyd CA Mccarroll D (2008) Multiple stable isotopes from oak trees in southwestern Scotland and the potential for stable isotope dendroclimatology in maritime climatic regions. Chemical Geology 252:62-71.

Maxwell RS, Hessl AE, Cook ER, Pederson N (2011) A multispecies tree ring reconstruction of Potomac River streamflow (950-2001). Water Resources Research.

47: W05512.

McCarroll D, Jalkanen R, Hicks S, Tuovinen M, Pawellek F, Gagen M, Eckstein D, Schmitt U, Autio J, Heikkinen O (2003) Multiproxy dendroclimatology: a pilot study in northern Finland. Holocene 13:829-838.

McCarroll D, Loader NJ (2004) Stable isotopes in tree rings. Quaternary Science Reviews 23:771-801.

McCarroll D, Gagen MH, Loader NJ, Robertson I, Anchukaitis KJ, Los S, Young GHF, Jalkanen R, Kirchhefer A, Waterhouse JS (2009) Correction of tree ring stable carbon isotope chronologies for changes in the carbon dioxide content of the atmosphere. Geochimica Et Cosmochimica Acta 73:1539-1547.

McLaughlin SB, Anderson CP, Hanson PJ, Tjoelker MG Roy WK (1991) Increased dark respiration and calcium deficiency of red spruce in relation to acidic deposition at high-elevation southern Appalachian Mountain sites. Canadian Journal of Forest Research 21:1234-1244.

McLaughlin SB, Tjoelker MG, Roy WK (1993) Acid deposition alters red spruce physiology: laboratory studies support field observations. Canadian Journal of Forest Research 23: 380-386.

McLaughlin SB, Tjoelker MJ (1992) Growth and physiological changes in red spruce saplings associated with acidic deposition at high elevations in the southern Appalachians, USA. Forest Ecology and Management 51: 43-51.

McLauchlan KK, Craine JM, Oswald WW, Leavitt PR, Likens GE (2007) Changes in nitrogen cycling during the past century in a northern hardwood forest. Proceedings of the National Academy of Sciences of the United States of America 104:7466-7470.

Morgan JA, Pataki DE, Körner C, Clark H, Del Grosso SJ, Grünzweig JM, Knapp AK, Mosier AR, Newton PCD, Niklaus PA, Nippert JB, Nowak RS, Parton WJ, Polley HW, Shaw MR (2004) Water relations in grassland and desert ecosystems exposed to elevated atmospheric $\mathrm{CO}_{2}$. Oecologia 140: 11-25. 
Morison JIL (1993) Response of plants to $\mathrm{CO}_{2}$ under water limited conditions. Vegetatio 104/105: 193-209.

O’Leary MH (1981) Carbon isotope fractionation in plants. Phytochemistry 20: 553-567.

Overdieck D, Forstreuter M (1994) Evapotranspiration of beech stands and transpiration of beech leaves subject to atmospheric $\mathrm{CO}_{2}$ enrichment. Tree Physiology 14: 997-1003.

Peñuelas J, Canadell JG, Ogaya R (2011) Increased water-use efficiency during the 20th century did not translate into enhanced tree growth. Global Ecology and Biogeography 20: 597-608.

Picon C, Guehl JM, Ferhi A (1996) Leaf gas exchange and carbon isotope composition responses to drought in a drought-avoiding (Pinus pinaster) and a drought tolerant (Quercus petraea) species under present and elevated atmospheric CO2 concentrations. Plant, Cell \& Environment.19:182190.

Saurer M, Siegwolf RTW, Schweingruber FH (2004) Carbon isotope discrimination indicates improving water-use efficiency of trees in northern Eurasia over the last 100 years. Global Change Biology, 10: 2109-2120.

Saurer M, Cherubini P, Reynolds-Henne CE, Treydte KS, Anderson WT, Siegwolf RTW (2008) An investigation of the common signal in tree ring stable isotope chronologies at temperate sites. Journal of Geophysical Research-Biogeosciences 113: G04035-G04046.

Schaberg PG, DeHayes DH, Hawley GJ (2001) Anthropogenic calcium depletion: a unique threat to forest ecosystem health? Ecosystem Health 7: 214-228.

Schleser GH, Helle G, Lücke A, Vos H (1999) Isotope signals as climate proxies: the role of transfer functions in the study of terrestrial archives. Quaternary Science Reviews 18: 927-943.

Sheppard PR, Casals P, Gutierrez E (2001) Relationships between ring-width and soil nutrient availability at the tree scale, Tree-Ring Research 57:105-113.

Silva LCR, Anand M, Leithead MD (2010) Recent widespread tree growth decline despite increasing atmospheric $\mathrm{CO}_{2}$. PLoS ONE 5(7): e11543. doi:10.1371/journal.pone.0011543

Smolnik M, Hessl A, Colbert JJ (2006) Species-specific effects of a 1994 ice storm on radial tree growth in Delaware, Journal of the Torrey Botanical Society 133:577-584.

Spiker EC, Hatcher PG (1987) The effects of early diagenesis on the chemical and stable carbon isotopic composition of wood. Geochimica et Cosmochimica Acta 51: 1385-1391.

Stenseth NC, Ottersen G, Hurrell JW, Mysterud A, Lima M, Chan K-S, Yoccoz NG, Ådlandsvik B (2003) Studying climate effects on ecology through the use of climate indices: the North Atlantic Oscillation, El Nino Southern Oscillation and beyond. Proceedings of the Royal Society of London (Series B) 270:2087-2096.

Stokes MA, Smiley TL An Introduction to Tree-Ring Dating (1968) University of Arizona Press, Tucson. 
Treydte K, Frank D, Esper J, Andreu L, Bednarz Z, Berninger F, Boettger T, D’Alessandro CM, Etien N, Filot M, Grabner M, Guillemin MT, Gutierrez E, Haupt M, Helle G, Hilasvuori E, Jungner H, Kalela-Brundin M,.Krapiec M, Leuenberger M, Loader NJ, Masson-Delmotte V, Pazdur A, Pawelczyk S, Pierre M, Planells O, Pukiene R, Reynolds-Henne CE, Rinne KT, Saracino A, Saurer M, Sonninen E, Stievenard M, Switsur VR, Szczepanek M, Szychowska-Krapiec E, Todaro L, WaterhouseJS , WeiglM, Schleser GH (2007) Signal strength and climate calibration of a European tree-ring isotope network. Geophysical Research Letters 34: L24302

Ward JK, Harris JM, Cerling TE, Wiedenhoeft A, Lott MJ, Dearing MD, Coltrain JB, Ehleringer JR (2005) Carbon starvation in glacial trees recovered from the La Brea tar pits, southern California. Proceedings of the National Academy of Sciences of the United States of America 102: 690-694.

Waterhouse JS, Switsur VR, Barker AC, Carte, AHC, Hemming DL, Loader NJ, Robertson I (2004) Northern European trees show a progressively diminishing response to increasing atmospheric carbon dioxide concentrations. Quaternary Science Reviews 23:803-810. 


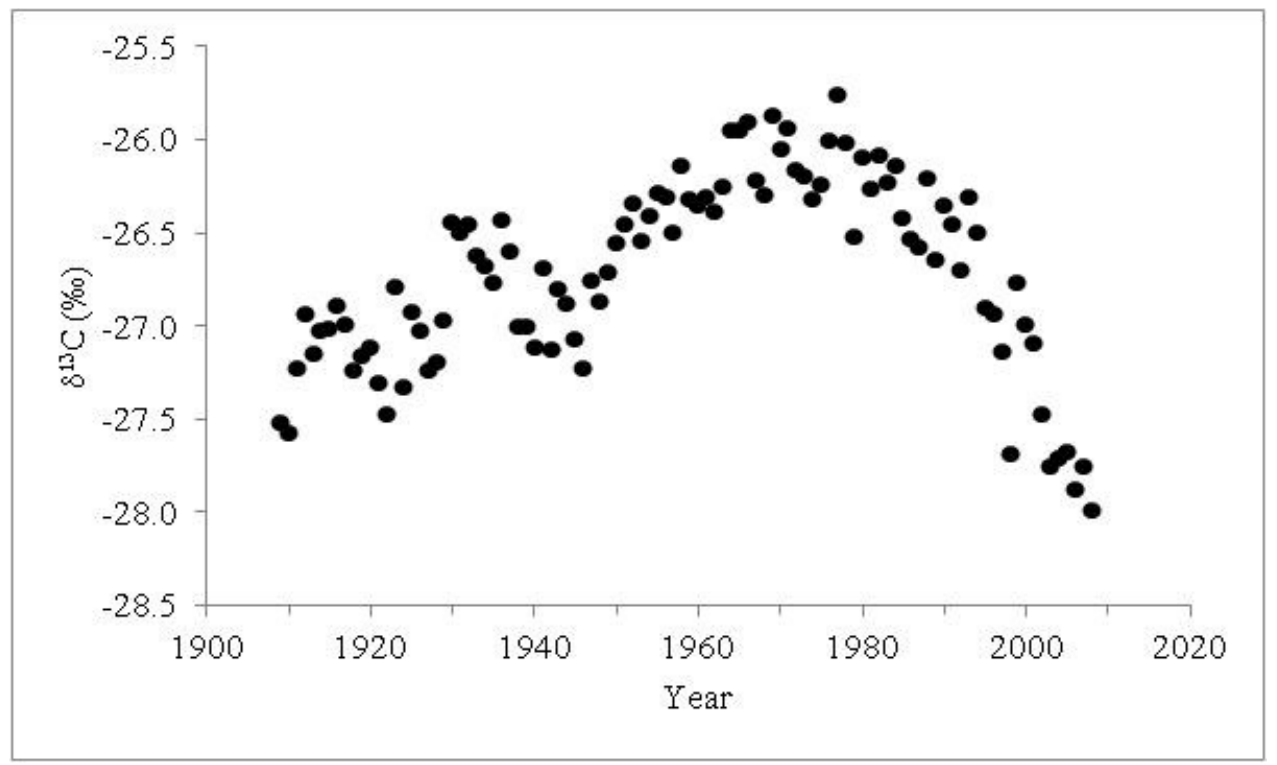

Figure 1. Mean whole wood carbon isotopic values $\left(\delta^{13} \mathrm{C}\right)$ from tree rings of Juniperus virginiana from 1909 to 2008 . Each $\delta^{13} \mathrm{C}$ value is the mean of 5 J. virginiana trees in the cedar glade stand. 


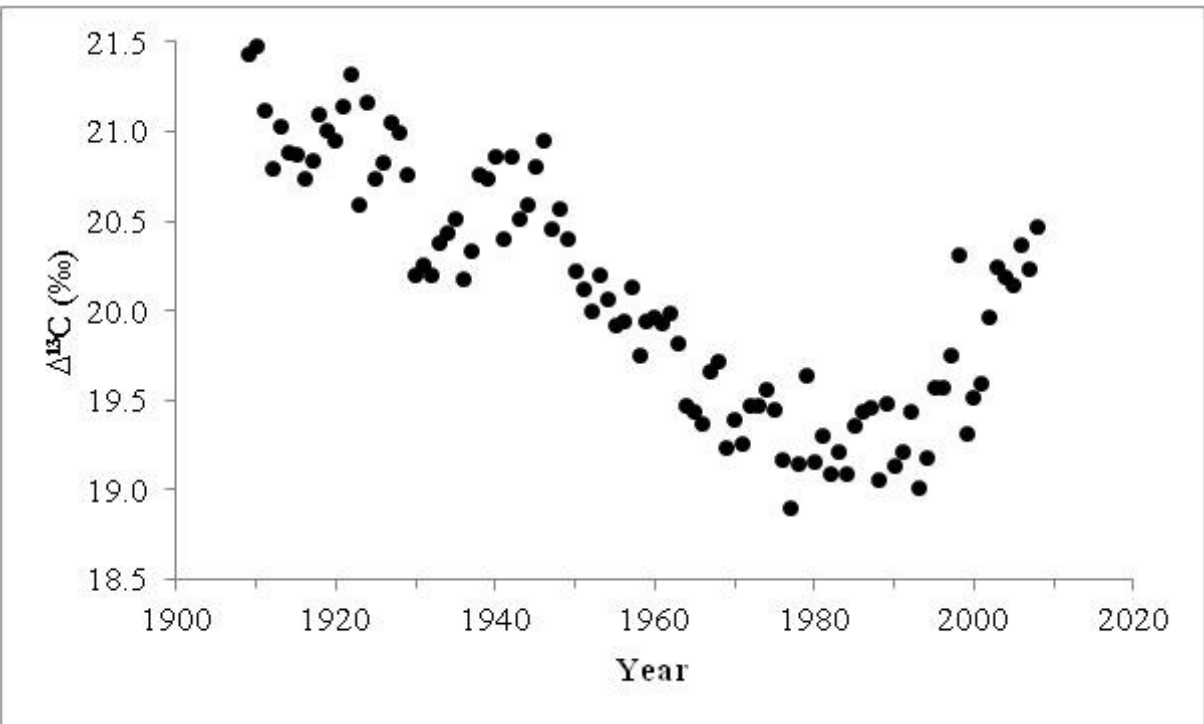

Figure 2. Carbon isotope discrimination $\left(\Delta^{13} \mathrm{C}\right)$ based on mean whole wood carbon isotopic values $\left(\delta^{13} \mathrm{C}\right)$ from tree rings of Juniperus virginiana from 1909 to 2008. Each $\Delta{ }^{13} \mathrm{C}$ value is the mean of $5 \mathrm{~J}$. virginiana trees in the cedar glade stand. 


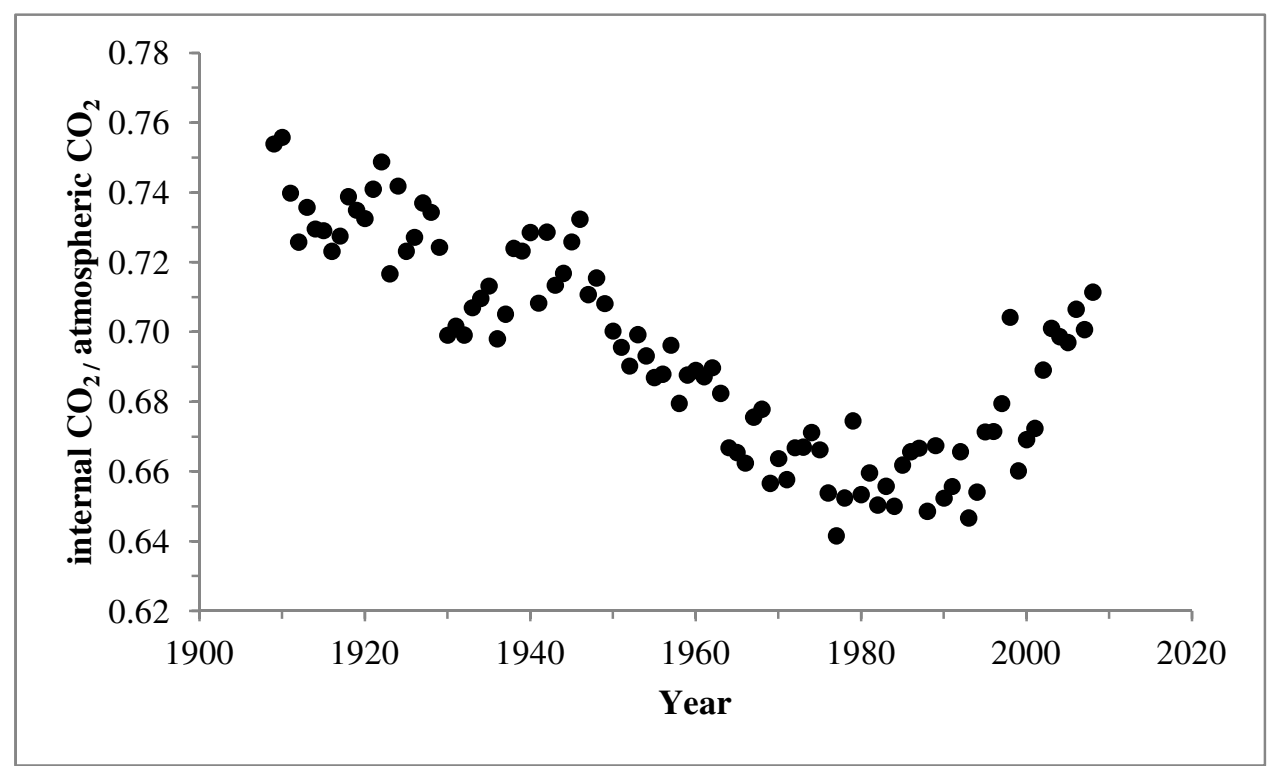

Figure 3. Temporal trend in the ratio of internal leaf $\mathrm{CO}_{2}$ concentrations to atmospheric $\mathrm{CO}_{2}$ concentrations $\left(\mathrm{C}_{i} / \mathrm{C}_{a}\right)$ of Juniperus virginiana trees calculated from whole wood $\delta^{13} \mathrm{C}$ from tree rings $(\mathrm{n}=5$ trees) and atmospheric $\delta^{13} \mathrm{C}$ over the last century. Values of atmospheric $\delta^{13} \mathrm{C}$ for the specific year of the tree ring were taken from direct atmospheric measurements (Scripps $\mathrm{CO}_{2}$ program, Scripps Institution of Oceanography; Keeling et al. 2010) and the Law Dome ice cores (Etheridge et al. 1998). 


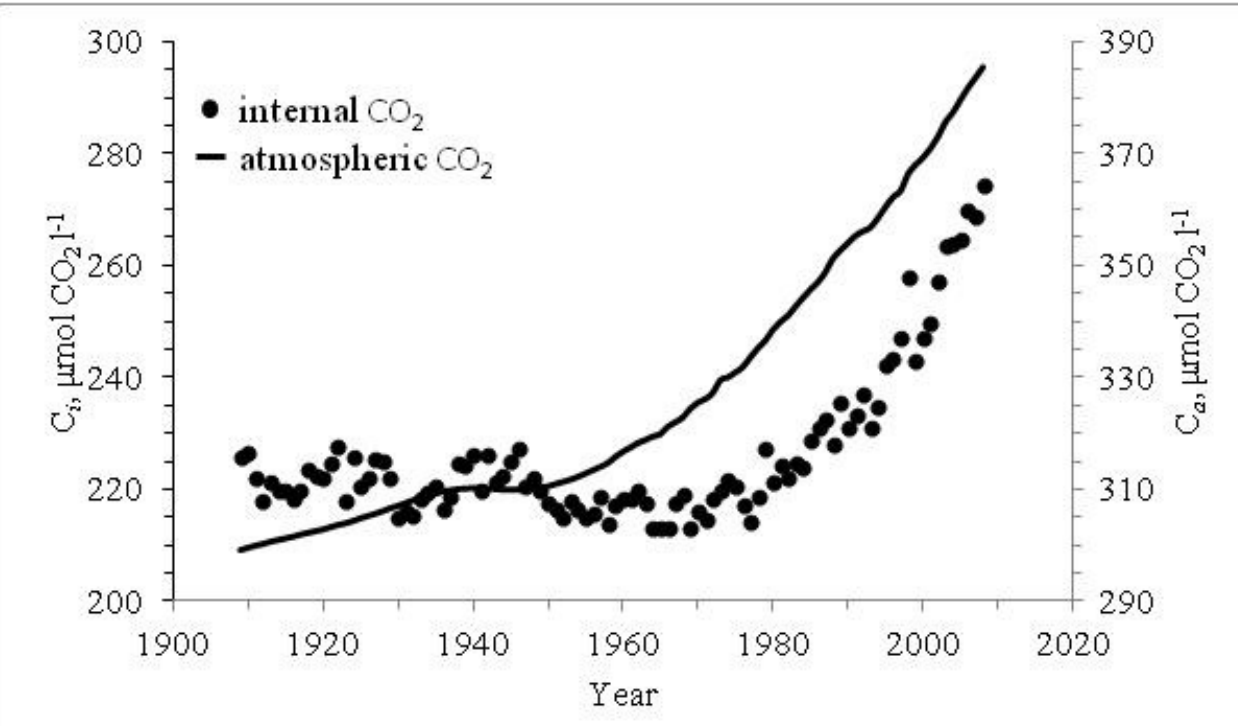

Figure 4. Temporal trend of internal $\mathrm{CO}_{2}$ concentrations $\left(\mathrm{C}_{i}\right.$, $\mu$ mol $\left.\mathrm{CO}_{2} \mathrm{l}^{-1}\right)$ and the corresponding atmospheric concentration $\left(\mathrm{C}_{a}, \mu \mathrm{mol} \mathrm{CO} \mathrm{C}^{-1}\right)$ for each year of the chronosequence. 


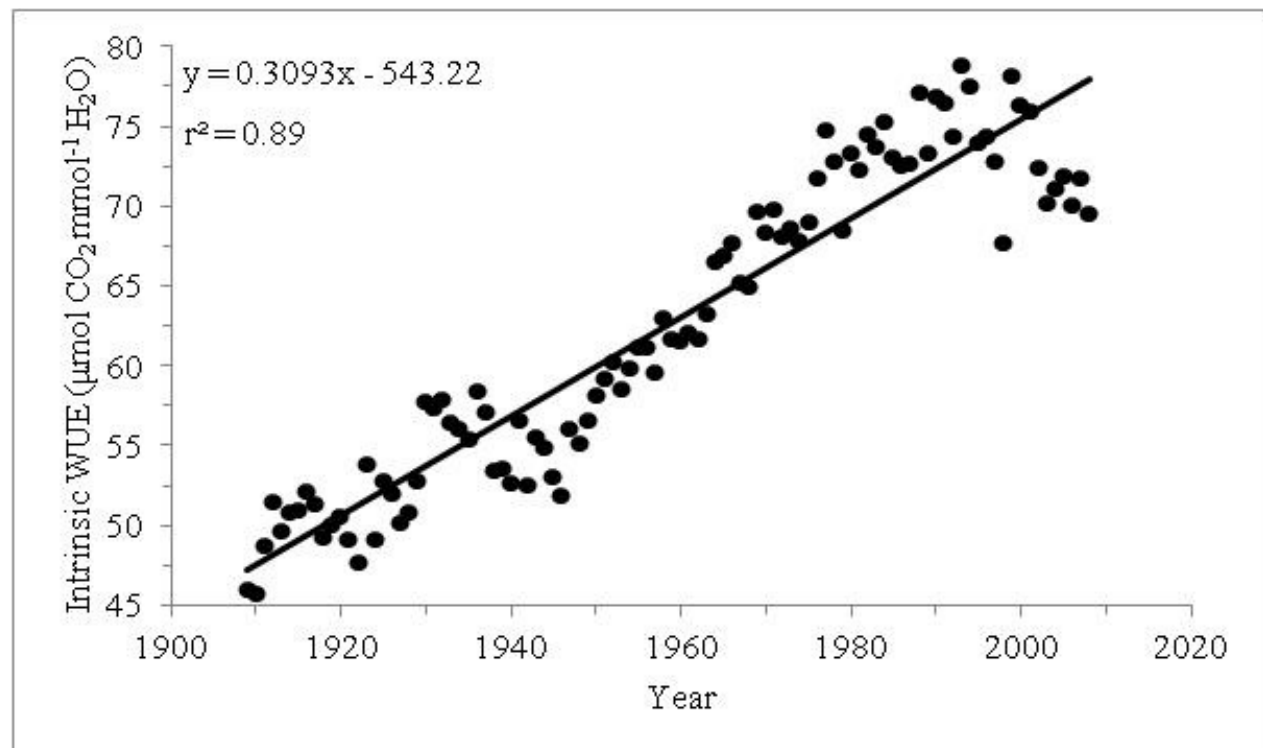

Figure 5. The relationship between intrinsic water use efficiency ( $i W U E)$ of Juniperus virginiana calculated from carbon isotope abundance of a chronosequence of tree rings from 1909 to 2008 ( $\mathrm{n}=5$ trees). Atmospheric values of $\mathrm{CO}_{2}$ concentration for the specific year of the tree ring were taken from direct atmospheric measurements (Scripps $\mathrm{CO}_{2}$ program, Scripps Institution of Oceanography; Keeling et al. 2010) or the Law Dome ice cores (Etheridge et al. 1998). 


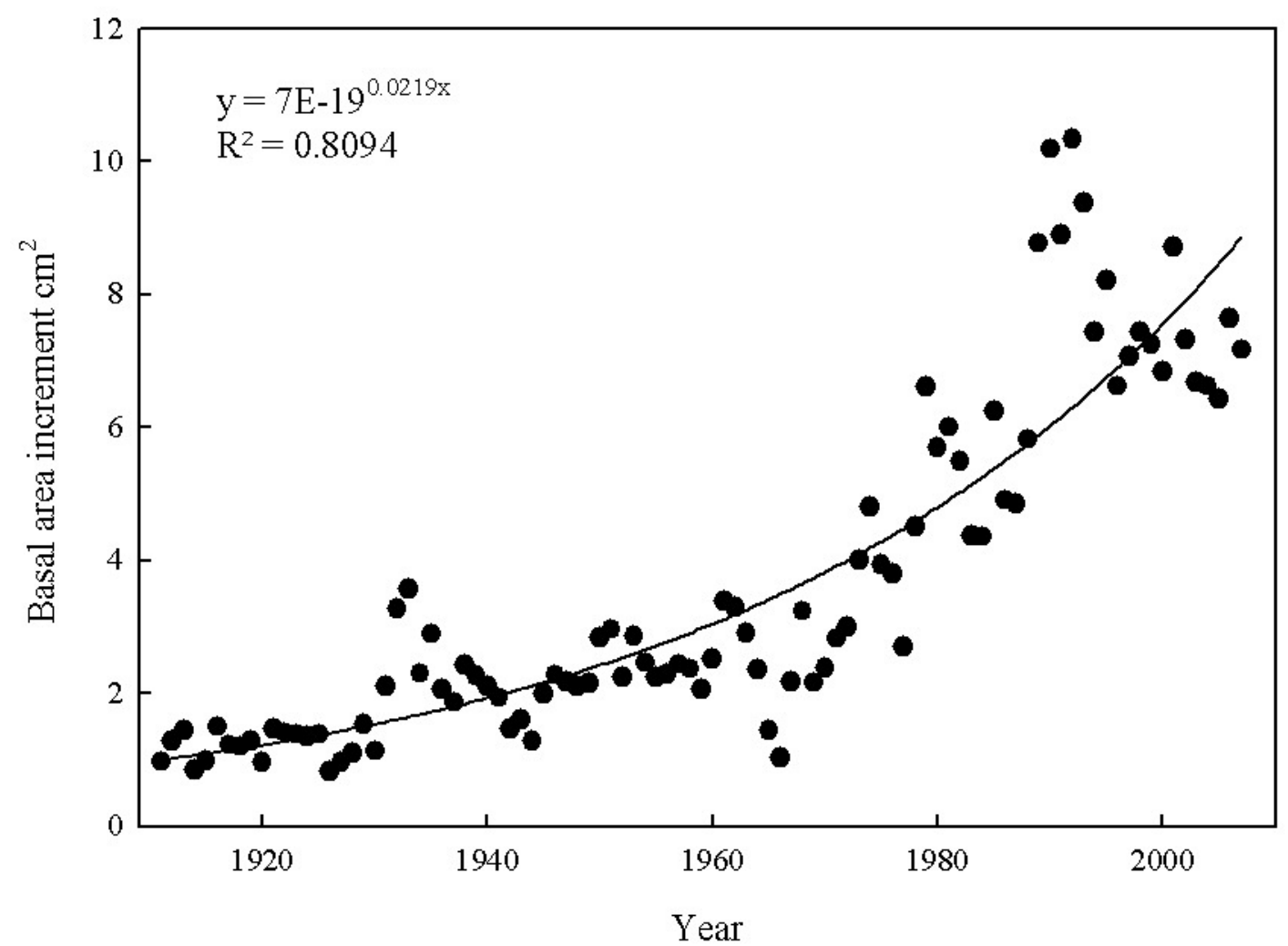

Figure 6. Temporal trend in the average annual basal area increment (BAI) of Juniperus virginiana trees growing over the past century on a cedar glade in Grant County, West Virginia, USA. Each value is the mean of 5 J. virginiana trees in the cedar glade stand. 


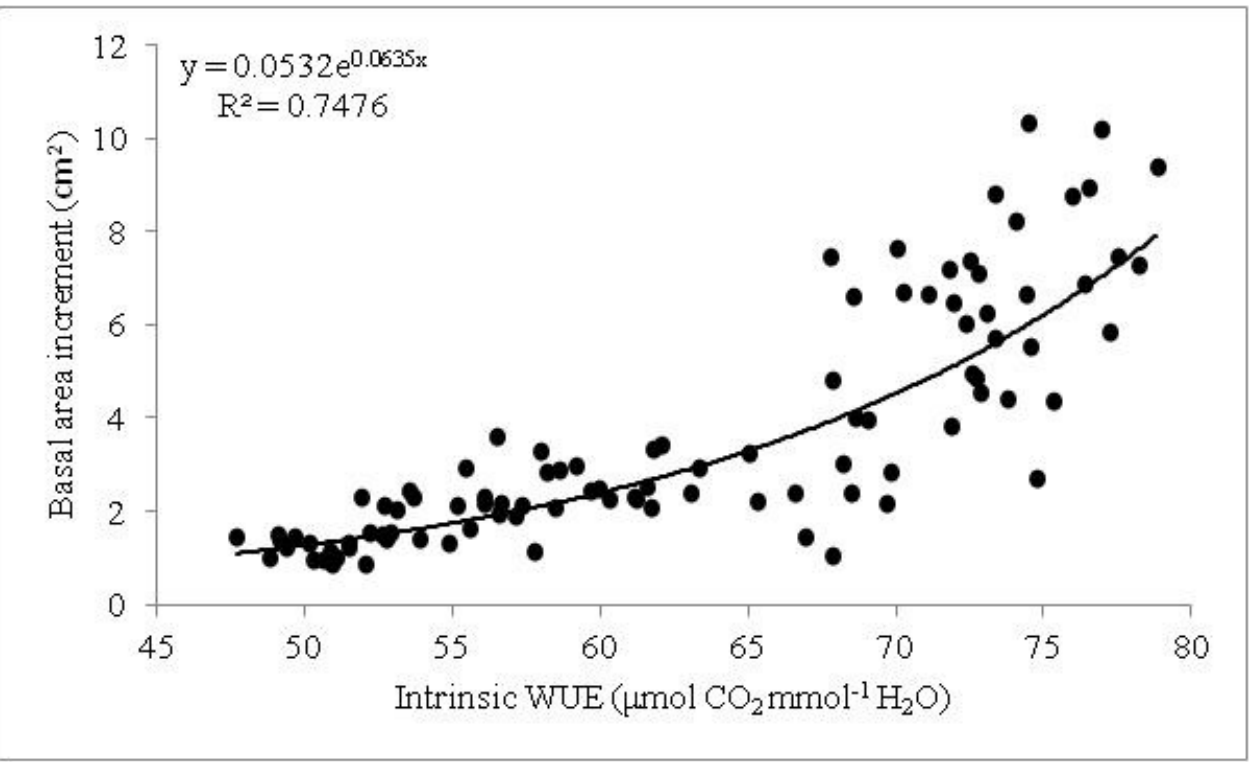

Figure 7. The relationship between intrinsic water use efficiency $(i W U E)$ and basal area increment (BAI) of Juniperus virginiana growing over the past century. Each value is the mean of $5 \mathrm{~J}$. virginiana trees in the cedar glade stand.

A $\mathrm{cm}^{2}$ 

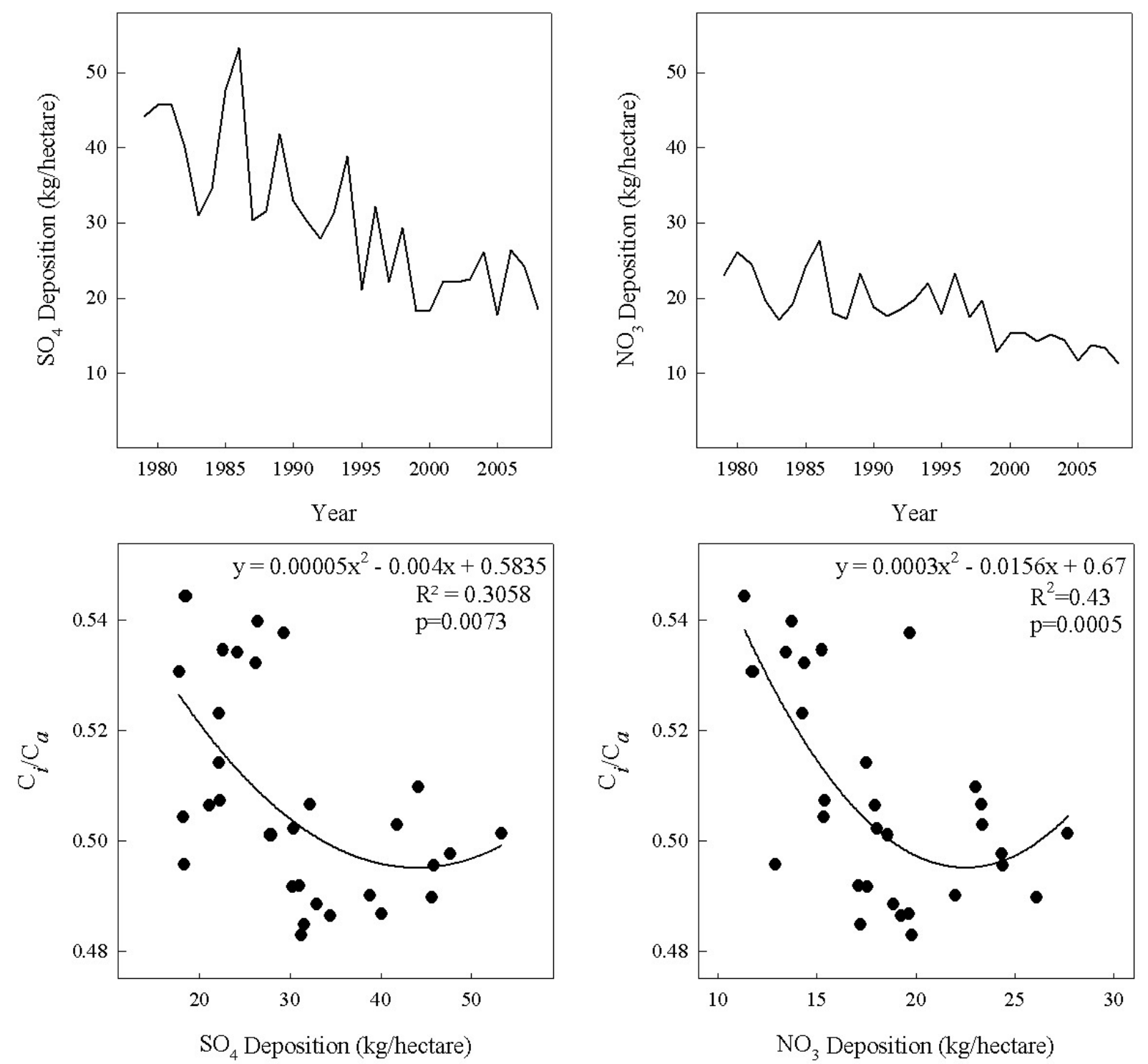

Figure 8. (Upper) Temporal trends in $\mathrm{SO}_{4}$ and $\mathrm{NO}_{3}$ deposition since 1978. (Lower) The relationship between $C_{i} / C_{a}$ ratio of Juniperus virginiana, as calculated from whole wood isotopic values, with $\mathrm{SO}_{4}$ and $\mathrm{NO}_{3}$ deposition (kg/ha) from 1978 to 2009. $\mathrm{SO}_{4}$ and $\mathrm{NO}_{3}$ deposition is from the National Atmospheric Deposition Program (NADP) at the NADP Monitoring Location WV18 in Parsons, WV, (http://nadp.sws.uiuc.edu/sites/siteinfo.asp?net=NTN\&id=WV18). 


\section{CHAPTER 4: Conclusions from my study}

Trees and forests are not static in time and a greater understanding of physiological functioning of forests as they age is central to our understanding of forest ecosystems. My thesis research used an old growth stand of Juniperus virginiana (Eastern red cedar) to examine how carbon assimilation changed over the last century. I first examined how tree age affects the physiological ecology of Juniperus virginiana in their native habitat; and second I used stable $\mathrm{C}$ isotopes in the annual growth rings to determine whether we could detect how climatic and environmental factors affected $\mathrm{C}$ assimilation and growth.

The observation that forest productivity declines as the trees in a forest age led me to hypothesize that I would see reductions in both hydraulic conductance and photosynthesis with tree age (reviews by Ryan et al. 1997; Pregitzer \& Euskirchen 2004; DeLucia et al. 2007). Ryan and Yoder (1997) proposed the hydraulic limitation hypothesis, that the decline in photosynthesis is linked to the reduced ability of trees to provision foliage with water. Investigation of the hydraulic limitation hypothesis in most studies have used trees that are both tall and old (e.g. Koch et al. 2004) and the effects of these two factors on hydraulic conductivity may be confounded. This study examined the physiological functioning of a chronosequence of J. virginiana trees that are approximately the same height $(6.77 \pm 0.54 \mathrm{~m})$ yet differ greatly in age $(98-481$ years).

My measurements of hydraulic conductance of J. virginiana trees supported the hydraulic limitation hypothesis in that age had no effect on hydraulic conductance. It is possible however that an age related decline in hydraulic conductance may be occurring before these trees reach 100 years of age. The stomatal and biochemical limitations of leaf photosynthesis of these trees across two growing seasons showed no relationship with tree age and were far more dependent of local climate. The $\delta^{13} C$ of leaf material did follow a pattern that supports the hydraulic limitation hypothesis, however in conjunction with the data it is far more likely that leaf morphology and nutrients contributed to these patterns.

Using the wood in annual rings of the same stand of J. virginiana trees as in the previous study I examined how $\delta^{13} C$, the ratio of internal leaf $\mathrm{CO}_{2}$ concentration $\left(C_{i}\right)$ to atmospheric $\mathrm{CO}_{2}$ concentration $\left(C_{a}\right)$, and instantaneous water use efficiency changed over the last one hundred years. Correlations between these parameters and records of climate and other environmental factors provided insight into changes in physiological functioning over longer time scales. This site-specific analysis helped to identify specific factors influencing carbon assimilation in J. virginiana and whether they are a good candidate for climate reconstruction.

Investigating the link between environmental conditions and physiological response, with regards to carbon, can be determined by understanding how $\mathrm{C}$ isotopes within the tree change over time (Farquhar et al. 1989). In this study, WUE was used to estimate the significance of stomatal changes in trees throughout the past century. I hypothesized that I would see increased water use efficiency (WUE) over the last century due 
to increases in $\mathrm{CO}_{2}$ concentration in the atmosphere and that productivity of red cedar would remain fairly constant.

The $C_{i} C_{a}$ ratios estimated from the isotopic composition of wood samples provided data of changes in stomatal regulation and WUE. The many factors that influence stomatal control make interpretations of WUE from $\delta^{13} C$ difficult (Farquhar and Sharkey 1982). Interestingly, the strongest relationship found between $C_{i} C_{a}$ and the environment was with nitrogen and sulfur deposition. This provides direct evidence of the influence of clean air regulations on forest productivity.

The strength of using changes in stable isotopes as part of a dendrochronological reconstruction of climate is that they provide a mechanistic link between isotopic composition of wood and environmental conditions. The dendrochronological analysis provided little evidence that this stand can be used for climate reconstruction. Weak relationships between climate and isotopic signature of wood were found, however the small sample size does not support using these data. The uses of multiple climate proxies (e.g., $\delta^{13} \mathrm{C}$ and $\delta^{18} \mathrm{O}$ ) in the future may make climate reconstruction more statistically powerful and enhance the ring width climate signal (Gagen et al. 2006).

By combining these two studies I was able to characterize the current physiology of Juniperus virginiana before attempting to understand past functioning. This is not a common component of dendrochronological studies and led to some interesting discoveries. This data highlights the pitfall of assuming that trees respond the same way to the environment over time. This can be seen when comparing the current year's data with the isotopic record. Additionally, the "environmental" component of dendrochronology should also include anthropogenic data such as pollution as a potential driver of change in physiological functioning. If this study only considered local climate we would have assumed that these trees were only responding to the changes in atmospheric concentrations of carbon dioxide. While this data set proved too small to statistically support making correlations with climate and larger climatic patterns, it does suggest that changes have occurred to the weather patterns of the eastern United States in the last century. 


\section{LITERATURE CITED}

DeLucia EH, Drake JE, Thomas RB, Gonzalez-Meler M (2007) Forest carbon use efficiency: is respiration a constant fraction of gross primary production? Global Change Biology 13: 1157-1167.

Farquhar GD, Sharkey TD (1982) Stomatal conductance and photosynthesis. Annual Review of Plant Physiology and Plant Molecular Biology 33: 317-345.

Gagen M, McCarroll D, Edouard JL (2006) Combining ring width, density and stable carbon isotope proxies to enhance the climate signal in tree-rings: An example from the southern French Alps. Climatic Change 78:363-379.

Farquhar GD, Ehleringer JR, Hubick KT (1989) Carbon isotope discrimination and photosynthesis. Annual Review of Plant Physiology and Plant Molecular Biology 40:503-537.

Koch GW, Sillett SC, Jennings GM, Davis SD (2004) The limits to tree height. Nature 428: 851-854.

Pregitzer KS, Euskirchen ES (2004) Carbon cycling and storage in world forests: biome patterns related to forests age. Global Change Biology 10: 2052-2077.

Ryan MG, Binkley D, Fownes JH (1997) Age-related decline in forest productivity: pattern and process. Advances in Ecological Research 27: 213-262.

Ryan MG, Yoder BJ (1997) Hydraulic limits to tree height and tree growth. Bioscience 47:235-242. 